\title{
ESTUDOS ANATÔMICOS E FISIOLÓGICOS DA \\ ORGANOGÊNESE IN VITRO EM Passiflora cincinnata MAST
}

\author{
SIMONE PACHECO LOMBARDI
}

Dissertação apresentada à Escola Superior de Agricultura "Luiz de Queiroz", Universidade de São Paulo, para obtenção do título de Mestre em Ciências, Área de Concentração: Fisiologia e Bioquímica de Plantas.

PIRACICABA

Estado de São Paulo - Brasil

Dezembro - 2003 


\section{ESTUDOS ANATÔMICOS E FISIOLÓGICOS DA ORGANOGÊNESE IN VITRO EM Passiflora cincinnata MAST}

\section{SIMONE PACHECO LOMBARDDI}

Engenheiro Agrônomo

Orientadora: Prof ${ }^{\circledR}$. Dr ${ }^{\mathrm{a}}$. BEATRIZ APPPEZZATO DA GLÓRIA

Dissertação apresentada à Escola Superior de Agricultura "Luiz de Queiroz", Universidade de São Paulo, para obtenção do título de Mestre em Ciências, Área de Concentração: Fisiologia e Bioquímica de Plantas.

PIRACICABA

Estado de São Paulo - Brasil

Dezembro - 2003 
Dados Internacionais de Catalogação na Publicação (CIP)

DIVISÃO DE BIBLIOTECA E DOCUMENTAÇÃO - ESALQ/ USP

\section{Lombarbi, Simone Pacheco}

Estudos anatômicos e fisiológicos da organogênese in vitro em Passiflora cincinnata Mast / Simone Pacheco Lombardi. -- Piracicaba, 2003. 60 p. : il. 2003

Dissertação (mestrado) - - Escola Superior de Agricultura Luiz de Queiroz, Bibliografia.

1.Ácido giberélico 2. Maracujá 3. Organogênese 4. Raiz 5. Regeneração “in vitro" 6. Regulador de crescimento I. Título

CDD 634.425 
$\mathcal{A}$ professora Beatriz pelos ensinamentos e por acreditar em mim,

OFEREÇO.

Aos meus pais, Francisco e Regina, que continuamente me apóiam e incentivam,

\section{DEDICO.}




\section{AGRADECIMENTOS}

Agradeço a todas as pessoas que, de forma direta ou indireta, contribuíram para a realização deste trabalho, especialmente :

À Profa. Dra. Beatriz Appezzato da Glória pela orientação, amizade e incentivo durante a realização deste trabalho.

À Profa. Dra. llene Ribeiro da Silva Passos, do Centro de Pesquisa e Desenvolvimento de Recursos Genéticos e Vegetais (CPDRGV), Instituto Agronômico de Campinas (IAC), pela orientação na cultura de tecidos e pela amizade.

A Profa. Dra. Maria Cristina Stolf Nogueira pela orientação nas análises estatísticas.

Ao Prof. Dr. Lázaro Eustáquio Pereira Peres, do Departamento de Ciências Biológicas da Escola Superior de Agricultura "Luiz de Queiroz" (ESALQUSP), pela amizade e pelas sugestões para a realização do presente trabalho.

Ao Prof. Dr. Ricardo Ferraz de Oliveira, pela amizade e pelos auxílios prestados.

À FAPESP, pela concessão da bolsa de estudos.

À farmacêutica Sra. Marli K. M. Soares, técnica do Laboratório de Anatomia Vegetal do Departamento de Ciências Biológicas (ESALQ-USP), pela amizade e pelo apoio técnico durante as atividades práticas.

Aos colegas Adriana Hayashi, Divina Vilhalva, João Paulo, Juliana Barbosa, Juliana Fernando, Laboratório de Anatomia Vegetal (ESALQ-USP), pela amizade, ensinamentos e incentivo em todos os momentos. 
À Milena Binatti Ferreira, técnica do laboratório do CPDRGV do IAC, pela amizade e pela ajuda no desenvolvimento das atividades práticas.

Aos colegas e funcionários do laboratório do CPDRGV, pela ajuda e amizade. Em especial a Ra uli, pelo apoio técnico.

Ao Sr. Oswaldo José S. Soares, pelos serviços fotográficos prestados.

A todos os professores, alunos e funcionários do Departamento de Ciências Biológicas da ESALQ - USP. Em especial aos secretários Solizete e Fábio, pela amizade e apoio.

Ao colega Amaral, pela amizade e pelos "inúmeros" auxílios prestados.

Aos funcionários do Setor de Biblioteca Central da ESALQ - USP, pelos auxílios prestados.

À coordenação do Programa de Pós-graduação em Fisiologia e Bioquímica de Plantas, por ter possibilitado a realização do presente trabalho.

Aos meus pais, Francisco e Regina, por incentivar e estimular meus estudos. Muito obrigada.

Ao meu querido Ricardo, pelo constante incentivo e apoio à realização do meu trabalho, pelo respeito, amor e carinho.

Aos meus avós, em especial ao vô Nicola, pela compreensão e pelas "caronas". 


\section{SUMÁRIO}

Página

RESUMO .............................................................................. viii

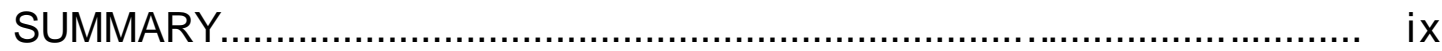

1 INTRODUÇÃO........................................................................... 1

2 MATERIAL E MÉTODOS.............................................................. 7

2.1 Efeito do ácido giberélico $\left(\mathrm{GA}_{3}\right)$ na germinação de sementes de

Passiflora cincinnata Mast................................................................. 7

2.2 Efeito do regulador vegetal 6 -benziladenina (6-BA) na organogênese in vitro de Passiflora cincinnata Mast...................................................... 8

2.2.1 Organogênese a partir de discos foliares e segmentos de raízes..................................................................................... 8

2.2.2 Organogênese a partir de plântulas, utilizadas

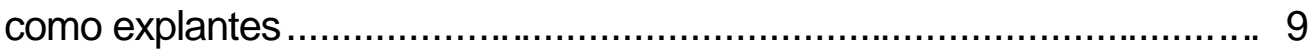

2.3 Estudo anatômico da organogênese in vitro................................... 10

2.4 Análise estatística............................................................................ 10

3 RESULTADOS E DISCUSSÃO ................................................. 11

3.1 Efeito do ácido giberélico $\left(\mathrm{GA}_{3}\right)$ na germinação de sementes de Passiflora cincinnata Mast.......................................................... 11

3.2 Efeito do regulador vegetal 6 -benziladenina (6-BA) na organogênese in vitro de Passiflora cincinnata Mast.............................................. 13

3.2.1 Disco foliar ............................................................................. 13

3.2.2 Segmento de raiz .................................................................... 16

3.2.3 Plântula .................................................................................. 18 
3.3 Análise morfológica...................................................................... 20

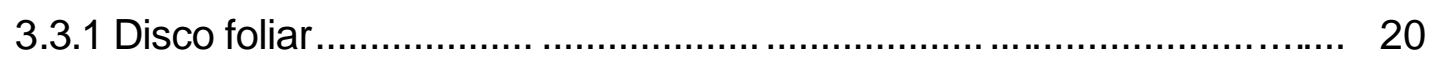

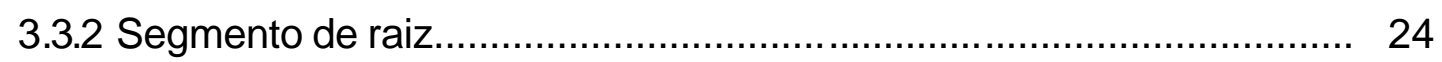

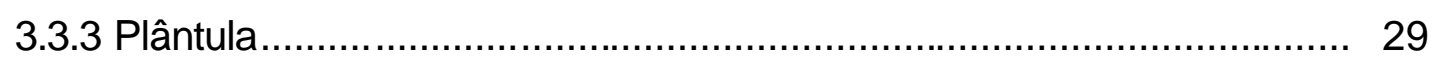

3.4 Análises anatômicas.................................................................... 35

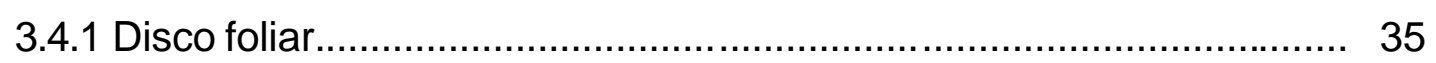

3.4.2 Segmento de raiz e plântula ............................................................. 37

4 CONCLUSÕES.

REFERÊNCIAS BIBLIOGRÁFICAS....................................................... 40

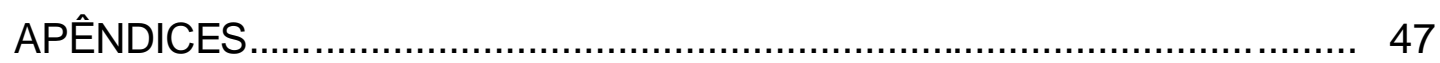




\title{
ESTUDOS ANATÔMICOS E FISIOLÓGICOS DA ORGANOGÊNESE IN VITRO EM Passiflora cincinnata MAST
}

\author{
Autora: SIMONE PACHECO LOMBARDI \\ Orientadora: Profa. Dra. BEATRIZ APPEZZATO DA GLÓRIA
}

\section{RESUMO}

O avanço da cultura do maracujazeiro no país impulsionado pela agroindústria de suco e a crescente demanda de fruta fresca, acarretou o surgimento de problemas, principalmente de ordem fitossanitária, doenças causadas por fungos, bactérias e vírus. A espécie Passiflora cincinnata Mast. por apresentar resistência à doença da parte aérea causada pela bactéria Xanthomonas campestris f. sp. passiflorae e, potencial para a comercialização constitui um genótipo de interesse em programas de melhoramento. Visto que a cultura de tecidos tem sido ferramenta importante nesses programas, 0 presente projeto visa o estudo aspectos anatômicos e fisiológicos da organogênese in vitro dessa espécie. Os explantes utilizados: segmentos radiculares, discos foliares e a própria plântula, obtidos da germinação de sementes in vitro, foram inoculados em meio contendo diferentes concentrações de 6-BA (6-benziladenina) e acrescido de $5 \%$ de água de coco, a fim de estabelecer os protocolos de regeneração de plantas in vitro. $A$ concentração de $0,5 \mathrm{mg} \cdot \mathrm{L}^{-1}$ de 6 -BA foi a mais adequada para os três 
explantes, porém, o tempo e a via (direta/indireta) de formação da gema diferiu para cada tipo de explante. Os eventos histológicos que levaram a formação de um novo órgão, via meristemóides (centros meristemáticos) foram descritos. Nos discos foliares a origem foi indireta, com formação de calo a partir das células subepidérmicas das camadas de parênquima clorofiliano. Nos segmentos de raiz e nas raízes das plântulas, a organogênese direta apresentou duas origens, a partir do periciclo, nas raízes com início da estrutura secundária, e a partir do câmbio vascular, nas raízes com estrutura secundária já estabelecida. Também nos segmentos de raiz observou-se a via indireta, esta a partir da proliferação do periciclo. 


\title{
ANATOMICAL AND PHYSIOLOGICAL STUDIES OF ORGANOGENESIS IN VITRO OF PASSIFLORA CINCINNATA MAST.
}

\author{
Author: SIMONE PACHECO LOMBARDI \\ Adviser: Profa. Dra. BEATRIZ APPEZZATO DA GLÓRIA
}

\section{SUMMARY}

The progress of passionfruit culture in the country stimulated by the juice agroindustry and due to an increased demand of fresh fruit have brought phytosanitary problems, such as, diseases caused by fungis, bacterium and virus. The Passiflora cincinnata Mast. a resistant specie to Xanthomonas campestris $\mathrm{f}$. $\mathrm{sp}$. Passiflora bacterium shows a potential for commercialization creating an interest genotype in breedings programs. Whereas the tissue culture has been an important instrument for those programs, object of this program is to study the anatomical and physiologycal aspects of organogenesis "in vitro" of this specie. The explants used were: root segments, leaf discs and the seedlings obtained from germination of seeds "in vitro". They were placed in different solutions of 6BA (benzyladenine) and with $5 \%$ of coconut water, in order to establish protocol for plant regeneration "in vitro". The concentration of $0,5 \mathrm{mg} . \mathrm{L}^{-}$ ${ }^{1}$ of 6-BA was the most adequate for all three explants, but the time and nourishement source (direct/indirect) to the shoots formation differed to each kind of explants. The histological events had lead the formation of a new organ, by meristemoids (meristematic centers) were described. In the leaf discs the indirect origin, was observed in which callus were formatted by the layer of chlorophyll parenchyma subepidermis cells. In the root segments and in the root 
plantets, the direct organogenesis showed two origins (source), from the pericycle, on the roots that starts at the secondary structure and from vascular cambium, on the roots that had already been established secondary structure. Also the root segments was seen by the indirect way, which callus were formatted by the pericycle proliferation. 


\section{INTRODUÇÃO}

O maracujazeiro pertence à ordem Passiflorales que possui três famílias, sendo a de maior interesse comercial a Passifloraceae, que compreende 18 gêneros que incluem cerca de 630 espécies, com distribuição principalmente nos trópicos da América, Ásia e África (Vanderplanck, 1996; Barbosa, 1998). Desses gêneros, destaca-se o Passiflora, com cerca de 150 espécies nativas do Brasil, das quais, mais de 60 produzem frutos que podem ser aproveitados direta ou indiretamente na alimentação (Teixeira, 1994; Barbosa, 1998).

O Brasil possui uma condição privilegiada quanto aos recursos genéticos de Passiflora, uma vez que o maior centro de dispersão geográfica do maracujá localiza-se no Centro-Norte do país (Meletti,1998).

O Brasil é o maior produtor mundial de maracujá, tendo cultivado aproximadamente 35.637 hectares. O cultivo é distribuído principalmente entre os estados do Pará, Bahia, São Paulo, Sergipe, Ceará, entre outros. Em 1999, São Paulo foi o segundo maior produtor com 59.155 toneladas (Agrianual, 2002). Porém, a falta de um cultivar homogêneo e produtivo, tolerante às principais moléstias que afetam a cultura do maracujá, dificulta o aumento da qualidade e da produtividade dos pomares comerciais.

No Brasil três espécies são responsáveis por praticamente $100 \%$ da área plantada, sendo elas o $P$. alata Dryand., popularmente conhecido como maracujá doce, $P$. edulis Sims., conhecido como maracujá roxo e P.edulis Sims f. flavicarpa Degener., conhecido como maracujá amarelo ou azedo, sendo esta última espécie responsável por $95 \%$ da área cultivada comercialmente no Brasil (FRUTAL, 2000). 
Várias espécies têm cultivo e consumo razoavelmente acentuado em regiões brasileiras específicas, entre as quais podemos citar Passiflora quadrangularis Linn., P.mollissima Bailey, P. nitida HBK, P. caerulea Linn., P. laurifolia Linn., P.coccinea Aubl., P.cincinnata Mast., P. ligularis Juss. e $P$. incarnata Linn (FRUTAL, 2000).

$P$. cincinnata Mast. possui ampla distribuição, principalmente na América tropical, ocorrendo desde o sul da América do Norte até ao Sul, ao longo da costa brasileira. Na Paraíba, a espécie é encontrada desde o litoral até a caatinga (Agra et al., 1996).

Esta espécie é popularmente conhecida como maracujá-mochila, maracujá-do-mato ou maracujá-tubarão. Possui flores muito vistosas, grandes e perfumadas e devido ao crescimento vigoroso e hábito trepador é considerada no litoral do nordeste do país como planta daninha. A espécie é perene e pode chegar até 4,5 m de comprimento, com gavinhas espiraladas com 6,0-12 cm comprimento e $0,1 \mathrm{~cm}$ diâmetro. Os frutos são bagas, ovóides com 5,0-6,0 cm diâmetro. As sementes têm 0,6 x 0,3 cm diâmetro, são ovais, faveoladas e negras (Nunes \& Queiroz, 2001).

Na caatinga paraibana a $P$. cincinnata Mast. apresenta características etnomedicinais, utilizam as folhas são utilizadas para o tratamento da hipotensão e como antiinflamatório. Os frutos são usados como calmante e antitussígeno (Agra et al.,1996).

A espécie apresenta resistência à doença da parte aérea causada pela bactéria Xanthomonas campestris f. sp. passiflorae (São José, 1994), sendo então um genótipo de interesse em programas de melhoramento.

As pesquisas com cultura de tecidos têm como um dos objetivos, possibilitar o desenvolvimento de plantas mais produtivas, resistentes às moléstias. As técnicas de cultura de tecidos têm sido empregadas de diferentes formas no desenvolvimento de cultivares superiores de plantas. Em geral, essas técnicas são utilizadas em uma ou outra etapa do melhoramento, não, necessariamente, no desenvolvimento direto de novos cultivares. As técnicas in vitro podem oferecer novas alternativas aos programas de melhoramento em suas diferentes fases e, muitas vezes, 
oferecem soluções únicas. São inúmeros os exemplos em que a introgressão de genes de importância agronômica de um acesso silvestre para um cultivar comercial foi realizada com o auxílio de cultura de embriões. Da mesma forma, a incorporação de genes via transformação genética depende da cultura de células, de tecidos ou órgãos para regeneração de plantas in vitro, mesmo quando a transformação se procede por meio de biobalística (Ferreira et al., 1998).

A organogênese é uma via de regeneração utilizada em estudos de cultura de tecidos. É o processo pelo qual células e tecidos são induzidos a sofrer mudanças que levam à produção de uma estrutura unipolar, denominada primórdio caulinar (caulogênese) ou de raiz (rizogênese), cujo sistema vascular está freqüentemente conectado ao tecido parental (Thorpe, 1994). É o processo pelo qual, tecidos vegetais produzem órgãos adventícios in vitro, podendo ocorrer direta (sem formação de calo) ou indiretamente, através da formação de calo (Burritt \& Leung, 1996; Alves, 1999). O calo é uma massa compacta de células desorganizadas, em diferentes estágios de desdiferenciação.

Rizogênese e caulogênese ocorrem em células e tecidos de plantas em resposta a manipulação dos níveis exógenos hormonais (Skoog \& Miller, 1957; Mercier et al., 2003). A aplicação exógena de reguladores vegetais pode facilitar este processo, mas não são imprescendíveis para que ocorra a organogênese (Christianson \& Warnick, 1988).

De acordo com Christianson e Warnick (1988), o processo de organogênese in vitro pode ser dividido em etapas: desdiferenciação, aquisição de competência, ind ução, determinação, diferenciação e formação do órgão. No processo da organogênese a competência seria entendida como a capacidade de responder ao estímulo hormonal necessário para indução da formação do órgão. Outro fator ligado à competência organogenética é o próprio metabolismo hormonal do explante, pois ele determina o balanço hormonal endógeno para a indução da organogênese (Peres \& Kerbauy, 1999). De fato, Mercier et al. (2003), em cultura in vitro de folhas de abacaxizeiro Ananas comosus cultivar "Smooth Cayenne", 
observaram uma intensa redução do balanço endógeno de auxina/citocininas nos primeiros dias de cultura, em função principalmente, de grande aumento na concentração de citocinina. Estes autores acreditam que a citocinina tenha desencadeado a sinalização indutora da resposta organogenética das bases foliares do abacaxizeiro.

Para espécies de Passiflora a regeneração de plantas pela organogênese e a micropropagação in vitro vem sendo obtida por vários autores. A maioria dos reguladores vegetais utilizados é do grupo das citocininas, principalmente BAP (benzilaminopurina), KIN (cinetina) e zeatina, podendo ser acrescidas pequenas concentrações de auxinas como NAA (ácido naftalenoacético), IAA (ácido indolilacético) ou 2,4-D (2,4-ácido diclorofenoxiacético) (Monteiro, 2000).

Kantharajah e Dodd (1990) descreveram um protocolo para micropropagação de $P$. edulis a partir de explantes nodais. Aparentemente, houve formação de gemas adventícias sem a produção de calos. A adição de água de coco (20\%) e de $2 \mathrm{mg} \cdot \mathrm{L}^{-1}$ de 6-BA no meio MS (Murashige \& Skoog, 1962) foram efetivas na produção de brotação.

Diferentes fontes de explantes, reguladores vegetais e concentrações de água de coco foram avaliados por Dornelas e Vieira (1994), utilizando espécies de Passiflora, incluindo $P$. edulis f. flavicarpa. Organogênese a partir de cotilédone, hipocótilo e discos foliares foi obtida nos explantes cultivados em meio contendo $1,0 \mathrm{mg} \cdot \mathrm{L}^{-1}$ de BAP, sob condições de 16 horas de luz. A adição de $10 \%$ de água de coco favoreceu a formação de gemas adventícias.

Os processos de regeneração de plantas in vitro podem ser avaliados e caracterizados pela análise histológica e morfológica do material vegetal. Estudos histológicos podem ser realizados para verificação e confirmação da via de regeneração, diferenciando-se organogênese de embriogênese somática (Vieira \& Appezzato-da-Glória, 2001). Caracterizando-se a via de regeneração, podem-se estabelecer melhores condições de cultivo, para o estabelecimento de protocolos eficientes para indução e obtenção de plantas. Cortes histológicos seriados, além de 
permitir a observação da formação da gema adventícia ou de embriões somáticos, definindo se são formados direta ou indiretamente, permitem caracterizar as alterações celulares e regiões do explante potencialmente morfogênicos (Monteiro-Hara, 2000).

Appezzato-da-Glória et al. (1999) observaram alterações celulares ocorridas em discos foliares de Passiflora edulis f. flavicarpa, testando efeito dos reguladores vegetais, BAP e NAA, e a presença ou ausência de luz na indução da organogênese. Os autores observaram a formação de centros meristemáticos após os 14 dias de cultura, e aos 28 dias, a formação de gemas adventícias resultantes destes centros, quando discos foliares cultivados em 1,0 mg.L ${ }^{-1}$ de BAP e presença de luz. Para a mesma espécie, Biasi et al. (2000), observaram em segmentos internodais que proliferações de células ocorriam nas extremidades excisadas dos explantes, e a diferenciação das gemas ocorriam nessa região, a partir do procâmbio.

Dado potencial da espécie Passiflora cincinnata Mast. para estudos de melhoramento, e a ausência de informações na literatura sobre a capacidade de formação de gemas em condições in vitro nesta espécie, este trabalho propõe:

a) estudar o efeito do ácido giberélico na germinação de sementes a fim de obter maior número de plântulas para a retirada dos explantes;

b) estudar diferentes concentrações da citocinina 6-BA, adicionada ao meio de cultura, na resposta organogênica de três explantes: segmentos radiculares, discos foliares e a própria plântula obtidos a partir de sementes germinadas in vitro;

c) monitorar anatomicamente o processo organogênico in vitro para as três fontes de explantes determinando a origem dos meristemóides e o processo de formação das gemas. 


\section{MATERIAL E MÉTODOS}

Foram utilizadas sementes da espécie Passiflora cincinnata Mast., coletadas no ano de 1999, da coleção de germoplasma do Instituto Agronômico de Campinas (IAC). A partir da germinação das sementes in vitro foram coletados os explantes: discos foliares, segmentos radiculares e as plântulas.

Os experimentos envolvendo cultura de tecidos foram realizados no laboratório do Centro de Pesquisa e Desenvolvimento de Recursos Genéticos e Vegetais, IAC.

O estudo anatômico dos explantes está sendo realizado no laboratório de Anatomia Vegetal do Departamento de Ciências Biológicas da Escola Superior de Agricultura "Luiz de Queiroz" (ESALQ) em Piracicaba.

\subsection{Efeito do ácido giberélico $\left(\mathrm{GA}_{3}\right)$ na germinação de sementes de Passiflora cincinnata Mast.}

As sementes foram colocadas em um béquer, lavadas com duas gotas de detergente adicionadas a $50 \mathrm{~mL}$ de água. As sementes foram enxaguadas em água corrente e para ampará-las utilizourse uma peneira plástica. A seguir foram imersas em etanol $70 \%$ por 40 segundos. Visando à retirada do arilo remanescente utilizourse um pano "Perfex", pois, o arilo prejudica descontaminação das sementes. A seguir as sementes de $P$. cincinnata foram embebidas em solução aquosa contendo diferentes concentrações do regulador $\mathrm{GA}_{3}\left(0,0 ; 500 ; 1000 \mathrm{mg}^{-\mathrm{L}^{-1}}\right)$ por 6 horas (tempo estabelecido para outras espécies de Passiflora em testes preliminares realizados no laboratório). 
A descontaminação das sementes foi efetuada em capela e fluxo laminar asséptico. As sementes foram imersas em uma solução de hipoclorito de cálcio a $2 \%$ durante 20 minutos, dentro de um erlenmayer autoclavado, sob agitação. Posteriormente, as sementes foram enxaguadas em solução levemente ácida, utilizando-se uma peneira plástica para ampará-las, sendo então tansferidas para outro erlenmayer autoclavado, livre de resíduos de hipoclorito de cálcio. O processo continuou com lavagens de água bidestilada autoclavada durante 20 minutos, trocando a água a cada cinco minutos, dando um total de quatro lavagens, no mesmo erlenmayer sob agitação. As sementes foram seccionadas (dois cortes laterais) e inoculadas em frascos contendo meio de cultura utilizado para a germinação composto por metade da concentração dos sais básicos e vitaminas de Murashige \& Skoog (1962), suplementado com $15 \mathrm{~g} . \mathrm{L}^{-1}$ de sacarose, solidificado com $6 \mathrm{~g} \cdot \mathrm{L}^{-1}$ de ágar, e o pH ajustado para 5,8, antes da adição de ágar e da autoclavagem a $120^{\circ} \mathrm{C}$ por 30 minutos. As culturas foram mantidas em sala de crescimento sob condições de fotoperíodo de $16 / 8$ horas, claro/escuro respectivamente, e temperatura de $25 \pm 1^{\circ} \mathrm{C}$. $\mathrm{O}$ delineamento experimental utilizado foi inteiramente casualizado com três tratamentos (concentrações do regulador $\mathrm{GA}_{3}: 0,0 ; 500 ; 1000 \mathrm{mg} \cdot \mathrm{L}^{-1}$ ) e quinze repetições (quinze frascos contendo cinco sementes). O melhor tratamento foi repetido para obtenção de explantes para os ensaios posteriores.

\subsection{Efeito do regulador vegetal 6-benziladenina (6-BA) na organogênese in vitro de Passiflora cincinnata Mast.}

\subsubsection{Organogênese a partir de discos foliares e segmentos de raízes.}

Para a obtenção desses explantes: discos foliares e segmentos de raízes, plântulas com 28 dias provenientes de sementes germinadas in vitro nas condições descritas no item 2.1 e não imersas em $\mathrm{GA}_{3}$, foram transferidas para frascos contendo meio de Murashige e Skoog (1962) 
acrescido de $5 \%$ de água de coco, visando maior desenvolvimento foliar e radicular. Após 28 dias, foram obtidos os discos foliares de $5 \mathrm{~mm}$ de diâmetro, a partir de folhas jovens, bem nutridas e expandidas, utilizando-se furador de rolhas. As raízes foram coletadas neste mesmo período, sendo segmentadas com 1 a $2 \mathrm{~cm}$ de comprimento a partir do ponto de inserção da raiz na plântula. Para cada explante foi instalado um experimento distinto. Foram colocados cinco explantes por frasco contendo $30 \mathrm{~mL}$ do meio Murashige e Skoog (1962), suplementado com $30 \mathrm{~g}^{-\mathrm{L}^{-1}}$ de sacarose, solidificado com $6 \mathrm{~g}$. L ${ }^{-1}$ de ágar, e adicionado de $5 \%$ de água de coco. $\mathrm{OpH}$ foi ajustado para 5,8 , antes da adição de ágar e da autoclavagem a $120^{\circ} \mathrm{C}$ por 30 minutos. As culturas foram mantidas em sala de crescimento sob as mesmas condições descritas no item 2.1. O delineamento experimental utilizado foi inteiramente casualizado, com cinco tratamentos $(0,0 ; 0,5 ; 1,0$; 1,$5 ; 2,0 \mathrm{mg} \cdot \mathrm{L}^{-1}$ de 6-BA) e quinze repetições.

Aos 28 dias de cultura, os explantes foram avaliados quanto à capacidade organogênica e transferidos para meio de mesma formulação. Aos 56 dias de cultura, foram contados os explantes organogênicos e 0 número de gemas por explante. Os dados foram analisados estatisticamente e as médias comparadas pelo teste de Tukey.

\subsubsection{Organogênese a partir de plântulas, utilizadas como explantes.}

Neste ensaio, as plântulas com 28 dias foram transferidas para meio de cultura descrito no item 2.2.1 e mantidas sob mesmas condições de crescimento. $O$ delineamento experimental utilizado foi inteiramente casualizado, com cinco tratamentos $\left(0,0 ; 0,5 ; 1,0 ; 1,5 ; 2,0 \mathrm{mg}^{-1} \mathrm{~L}^{-1}\right.$ de 6 -BA) e quinze repetições. Em cada frasco (repetição), contendo $30 \mathrm{~mL}$ de meio de cultura, foi colocado apenas um explante, pois este apresentou grande desenvolvimento, limitando o espaço físico. Aos 28 dias, os explantes foram transferidos para meio fresco de mesma formulação sendo contados os explantes organogênicos por tratamento. Aos 56 dias repetiurse a avaliação de contagem de explantes organogênicos por tratamento e também foi 
avaliado o número de gemas por explante. Os dados foram analisados estatisticamente.

\subsection{Estudo anatômico da organogênese in vitro}

Os explantes foram coletados periodicamente $(7,14,21,28,35,42$, 49, 56 dias) ao longo do experimento visando a caracterização histológica do processo organogênico. As amostras foram fixadas em solução de Karnovsky (Karnovsky, 1965) e foram levadas à bomba de vácuo para retirada do ar contido nos espaços intercelulares. Após a fixação, as amostras foram desidratadas em série etílica e infiltradas com a resina glicol metacrilato da Reichert-Jung. As secções (5 $\mu \mathrm{m}$ de espessura) feitas em micrótomo rotativo manual (Leica), foram coradas com azul de toluidina 0,05\% em tampão fosfato e ácido cítrico (Sakai, 1973) e montadas em resina sintética "Entellan” (Merck).

As lâminas estão sendo fotomicrografadas em microscópio NIKON AFX-DX, com a escala micrométrica fotografada e ampliada nas mesmas condições ópticas utilizadas.

\subsection{Análise estatística}

A análise estatística foi realizada pelo sistema SAS considerando o delineamento inteiramente casualizado, com 15 repetições. Foi utilizada a transformação $\mathrm{x}$ para os dados de número sementes germinadas, número de explantes organogênicos e para a média do número de gemas, na análise do ensaio com disco foliar e plântula, e a transformação logarítimo para a média do número de gemas na análise do ensaio com segmento de raiz.

As médias dos dados transformados foram comparadas pelo teste de Tukey, com intervalo de confiança de 0,05. 


\section{RESULTADOS E DISCUSSÃO}

3.1 Efeito do ácido giberélico $\left(\mathrm{GA}_{3}\right)$ na germinação de sementes de Passiflora cincinnata Mast.

A análise dos dados de porcentagem de sementes germinadas revelou que não houve diferença significativa entre as concentrações de $\mathrm{GA}_{3}$ utilizadas (Tabela 1).

Tabela 1. Porcentagem de sementes germinadas de Passiflora cincinnata em meio $M S / 2$ após embebição das sementes em solução contendo ou não $\mathrm{GA}_{3}$

\begin{tabular}{cccc}
\hline & \multicolumn{3}{c}{ Germinação } \\
Tratamentos & $\begin{array}{c}\text { Sem transformação } \\
\text { (porcentagem) }\end{array}$ & $\begin{array}{c}\text { Transformados } \\
\text { (porcentagem) }\end{array}$ \\
\hline $\mathbf{1}$ (0,0) $\left.^{-1} \mathbf{G A}_{3}\right)$ & 52 & 70,90 & $\mathbf{A}$ \\
$\mathbf{2}(\mathbf{5 0 0})$ & 30 & 48,31 & $\mathbf{A}$ \\
$\mathbf{3 ( 1 0 0 0 )}$ & 36 & 56,50 & $\mathbf{A}$ \\
\hline
\end{tabular}

Coneglian et al. (1999) verificaram que sementes de $P$. alata germinaram melhor quando colocadas num substrato umedecido com 300 mg. $\mathrm{L}^{-1}$ de $\mathrm{GA}_{3}$. Também Rosseto et al. (1999), observaram que sementes de $P$. alata pré-embebidas por $24 \mathrm{~h}$ em soluções de $\mathrm{GA}_{3} 150$ e $300 \mathrm{mg}^{-1}$ apresentaram melhores respostas de germinação quando comparadas com o controle. Em ambos trabalhos com $P$. alata os autores não apresentaram os valores de porcentagem de germinação. 
Melo (1999) obteve $46,7 \%$ de germinação quando sementes de $P$. nitida foram imersas em solução contendo $1500 \mathrm{mg} \cdot \mathrm{L}^{-1}$ de $\mathrm{GA}_{3}$. Segundo o autor, $0 \mathrm{GA}_{3}$ mostrou-se eficaz na quebra de dormência antecipando a germinação de $P$. nitida.

Por sua vez, em $P$. cincinnata, a porcentagem de germinação na ausência do regulador vegetal foi de $52 \%$, superior àquela considerada por Melo (1999) como melhor resposta em $P$. nitida à imersão em GA $_{3}$ (1500 $\left.\mathrm{mg} \cdot \mathrm{L}^{-1}\right)$. Comparando-se os resultados obtidos neste estudo com os poucos relatos na literatura sobre o efeito do $\mathrm{GA}_{3}$ na germinação de sementes de espécies de Passiflora observa-se que as concentrações e o tempo de embebição variam entre as espécies.

A porcentagem alcançada na ausência de $\mathrm{GA}_{3}$ mostrou-se satisfatória para a obtenção do número de explantes necessários para o estudo da organogênese tendo sido este tratamento repetido nos demais ensaios. É provável que a rigidez do tegumento da semente de $P$. cincinnata (Figura 1) tenha dificultado a absorção da solução contendo o $\mathrm{GA}_{3}$ interferindo na resposta obtida no ensaio.
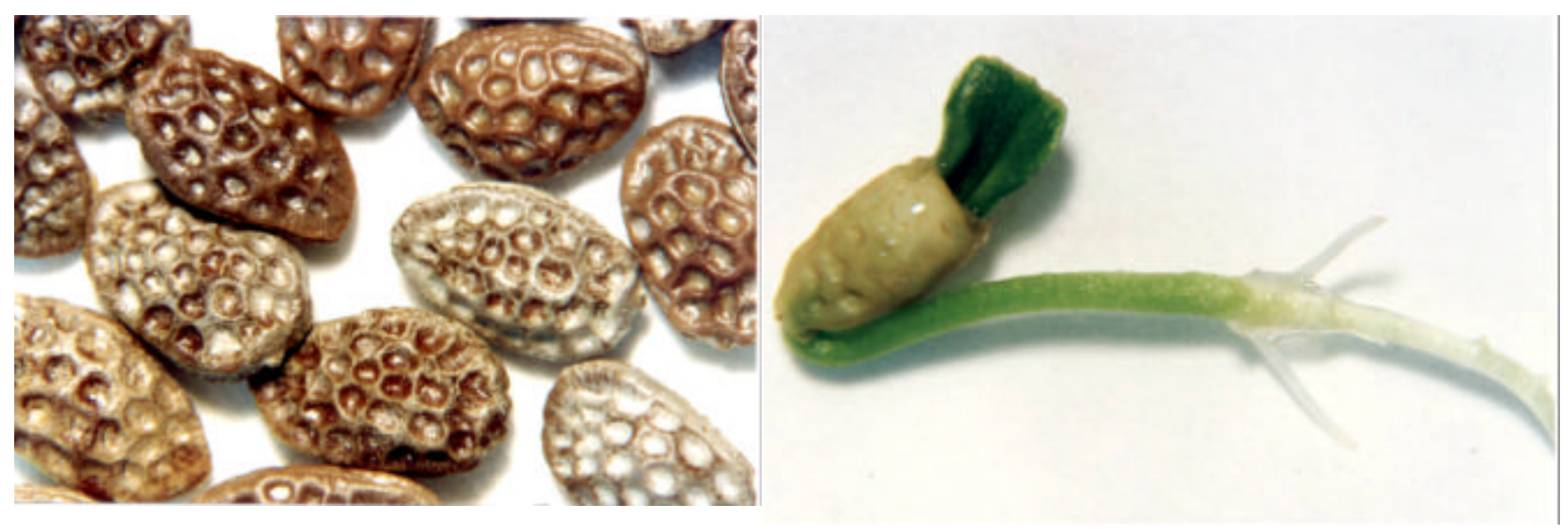

Figura 1 - Sementes de Passiflora cincinnata e germinação de uma delas. (Fotos: llene Passos). Barra $=2 \mathrm{~mm}$ 


\subsection{Efeito do regulador vegetal 6-benziladenina (6-BA) na organogênese} in vitro de Passiflora cincinnata Mast.

\subsubsection{Disco foliar}

A formação de gemas nos discos foliares foi observada após a formação de calo nas extremidades do explante. A organogênese indireta em $P$. cincinnata somente ocorreu em meio de cultura contendo o regulador 6-BA (Tabelas 2 e 3), o que também foi observado em segmentos do entrenó de $P$. edulis f. flavicarpa (Biasi et al., 2000) e em discos foliares de Passiflora suberosa (Monteiro et al., 2000). Em P. edulis f. flavicarpa, a organogênese direta a partir de discos foliares foi descrita por Dornelas e Vieira (1994), aos 28 dias de cultura em meio MS contendo $1,0 \mathrm{mg} . \mathrm{L}^{-1}$ de 6BA. Nestas condições, a resposta de explantes com capacidade de regeneração foi de $66,6 \%$ e $33,3 \%$, a partir de explantes cotiledonares e hipocotiledonares, respectivamente, e $41,7 \%$ para discos foliares. Se compararmos com os resultados obtidos por Dornelas e Vieira (1994), a espécie $P$. cincinnata apresentou-se mais eficiente na competência organogênica, pois com metade da concentração de 6-BA, obteve 43,5\% de resposta organogênica aos 28 dias de cultura.

Por outro lado, em espécies selvagens ( $P$. molissima, $P$. giberti, $P$. maliformis e $P$. amethystina), a organogênese ocorreu diretamente na superfície dos explantes discos foliares, em meio contendo 1,0 mg.L ${ }^{-1}$ 6-BA. Aos 28 dias de cultura, a espécie $P$. giberti e $P$. molissima apresentaram $70 \%$ e $10 \%$ de explantes organogênicos, respectivamente. Entretanto, em $P$. cincinnata a melhor resposta organogênica foi obtida em meio contendo 0,5 mg. $L^{-1}$ de $6-B A$, onde aos 28 dias de cultura $43,5 \%$ dos explantes formaram gemas, e aos 56 dias de cultura apresentou $70 \%$ de explantes organogênicos (Tabela 2), o que Dornelas e Vieira (1994) obtiveram em menor tempo para a espécie $P$. giberti, pelo fato da via de regeneração ser direta. 
Os resultados obtidos, porcentagem de explantes organogênicos e número médio de gemas por explante podem ser observados nas tabelas 2 e 3, respectivamente. Aos 28 dias de cultura, podemos observar que o tratamento 2 apresentou melhor resposta organogênica em menor tempo de cultura (Tabela 2). Entretanto, observourse que entre os dois períodos de avaliação, o tratamento 4 triplicou sua resposta.

Tabela 2. Porcentagem de explantes (discos foliares) organogênicos de Passiflora cincinnata aos 28 e 56 dias de cultura em meio contendo $5 \%$ de água de coco e diferentes concentrações de 6BA. Os dados originais são os da coluna sem transformação

\begin{tabular}{|c|c|c|c|c|}
\hline \multirow{3}{*}{$\begin{array}{l}\text { Tratamentos } \\
\left.\text { (mg.L }{ }^{-1} 6-B A\right)\end{array}$} & \multicolumn{4}{|c|}{ Explantes organogênicos } \\
\hline & \multicolumn{2}{|c|}{$\begin{array}{c}\text { Sem transformação } \\
(\%)\end{array}$} & \multicolumn{2}{|c|}{ Transformados (\%) } \\
\hline & 28 dias & 56 dias & 28 dias & 56 dias \\
\hline $1(0,0)$ & 0,00 & 0,00 & $0,00 \mathrm{C}$ & $0,00 \mathrm{~B}$ \\
\hline $2(0,5)$ & 29,33 & 54,66 & $43,49 \mathrm{~A}$ & $69,25 \mathrm{~A}$ \\
\hline $3(1,0)$ & 13,33 & 41,33 & $18,61 \mathrm{BC}$ & $56,21 \mathrm{~A}$ \\
\hline $4(1,5)$ & 13,33 & 56,00 & $26,03 \mathrm{AB}$ & $72,23 \mathbf{A}$ \\
\hline $5(2,0)$ & 0,00 & 11,42 & $0,00 \mathbf{C}$ & $19,63 \mathbf{B}$ \\
\hline
\end{tabular}

As letras iguais indicam que não há diferença significativa.

Tabela 3. Número médio de gemas por explante (disco foliar) em Passiflora cincinnata aos 56 dias de cultura em meio MS contendo diferentes concentrações de 6-BA e 5\% de água de coco

\begin{tabular}{|c|c|c|}
\hline \multirow{2}{*}{$\begin{array}{l}\text { Tratamentos } \\
\text { (mg.L }{ }^{-1} \text { 6-BA) }\end{array}$} & \multicolumn{2}{|c|}{ Gemas/ explante } \\
\hline & Sem transformação & Transformados \\
\hline $1(0,0)$ & 0,0000 & 0,0000 B \\
\hline $2(0,5)$ & 3,8933 & $1,8027 \mathbf{A}$ \\
\hline $3(1,0)$ & 2,3200 & $1,1673 \mathbf{A}$ \\
\hline $4(1,5)$ & 1,9600 & $1,2568 \mathbf{A}$ \\
\hline $5(2,0)$ & 0,2000 & 0,2415 B \\
\hline
\end{tabular}

As letras iguais indicam que não há diferença significativa. 
Embora os tratamentos 2, 3 e 4 não tenham diferido significativamente, a melhor resposta foi aquela com a menor concentração do regulador. A ausência do regulador 6-BA e a mais elevada concentração (2,0 mg. $\left.\mathrm{L}^{-1}\right)$ não foram favoráveis para a formação de gemas. Porém, em $P$. edulis f. flavicarpa a concentração de $2,0 \mathrm{mg} \cdot \mathrm{L}^{-1}$ 6-BA foi satisfatória para a indução da organogênese e doses superiores a 2,0 mg. $\mathrm{L}^{-1}$ foram prejudiciais ao crescimento das gemas (Dornelas \& Vieira, 1994; Biasi et al., 2000).

Kantharaj e Dodd (1990), realizaram experimento de micropropagação de $P$. edulis, a partir de explantes nodais, testando duas concentrações de sacarose ( $2 \%$ e $3 \%$ ), ausência e presença de água de coco (20\%), combinado com três concentrações de BAP $\left(1,0,2,0\right.$ e 3,0 mg. L $^{-}$ $\left.{ }^{1}\right)$. Segundo os autores, o efeito das duas concentrações de sacarose não foi significativo na multiplicação de brotos, mas a presença de água de coco apresentou aumento na produção de brotos por explante. A concentração de 2,0 mg. $\mathrm{L}^{-1}$ de BAP foi a mais eficaz na produção de brotos. Segundo Hall et al. (2000), para muitas espécies, incluindo Passiflora, a água de coco contém substâncias de crescimento essenciais para uma maior regeneração. Em explantes foliares de espinafre, a água de coco adicionada ao meio de cultura aumentou o vigor e promoveu o rápido desenvolvimento de brotos (Al-Khayri et al. 1992; Hall et al. 2000). Para a regeneração de maracujá, Hall et al. (2000) utilizaram água de coco e obtiveram efeito similar aos observados em espinafre, o rápido desenvolvimento de brotos e o aumento na altura dos brotos. O número de explantes com brotos foi também maior quando combinado BAP e água de coco. 


\subsubsection{Segmento de raiz}

Os resultados obtidos, porcentagem de explantes organogênicos e número médio de gemas por explante podem ser observados nas tabelas 4 e 5, respectivamente.

O número médio de gemas não variou significativamente, sendo que a melhor resposta foi obtida com $0,5 \mathrm{mg} \cdot \mathrm{L}^{-1}$ 6-BA (Tabela 5). A formação de gemas nos segmentos de raízes na ausência do regulador vegetal (tratamento 1) surpreendeu, pois este evento não foi observado nos discos foliares. Em Curcuma zeadoaria (Melo et al., 2000), a combinação dos reguladores NAA e BA favoreceu a organogênese indireta em explantes radiculares, o processo de formação foi semelhante ao observado para a espécie $P$. cincinnata.

Tabela 4. Porcentagem de explantes (segmentos radiculares) organogênicos de Passiflora cincinnata aos 28 e 56 dias de cultura em meio contendo $5 \%$ de água de coco e diferentes concentrações de 6 BA. Os dados originais são os da coluna sem transformação

\begin{tabular}{ccccc}
\hline & \multicolumn{4}{c}{ Explantes organogênicos } \\
Tratamentos & Sem transformação (\%) & \multicolumn{2}{c}{ Transformados (\%) } \\
(mg.L $\left.{ }^{-1} \mathbf{6 - B A}\right)$ & $\mathbf{2 8}$ dias & 56 dias & 28 dias & 56 dias \\
\hline $\mathbf{1 ( 0 , 0 )}$ & 55 & 71,67 & $72,32 \mathbf{A}$ & $84,14 \mathbf{A}$ \\
$\mathbf{2 ( 0 , 5 )}$ & 60 & 70 & $77,09 \mathbf{A}$ & $83,33 \mathbf{A}$ \\
$\mathbf{3 ( 1 , 0 )}$ & 46,67 & 76,36 & $67,44 \mathbf{A}$ & $87,13 \mathbf{A}$ \\
$\mathbf{4 ( 1 , 5 )}$ & 50,90 & 76,36 & $69,61 \mathbf{A}$ & $87,13 \mathbf{A}$ \\
$\mathbf{5 ( 2 , 0 )}$ & 25 & 50 & $42,80 \mathbf{B}$ & $69,26 \mathbf{B}$ \\
\hline
\end{tabular}

As letras iguais indicam que não há diferença significativa.

$\mathrm{O}$ isolamento da raiz pode ter alterado 0 balanço endógeno auxina/citocinina, favorecendo a citocinina, visto que as raízes são os principais centros produtores de citocinina na planta (Van Staden \& Smith, 
1978). A concentração endógena de citocinina pode ter influenciado na resposta do tratamento 5, causando redução na resposta organogênica.

Tabela 5. Número médio de gemas por explante (segmento de raiz) em Passiflora cincinnata aos 56 dias de cultura em meio MS contendo diferentes concentrações de 6-BA e 5\% de água de coco

\begin{tabular}{ccc}
\hline $\begin{array}{c}\text { Tratamentos } \\
\left.\text { (mg.L }{ }^{-1} \mathbf{6 - B A}\right)\end{array}$ & \multicolumn{2}{c}{ Gemas/ explante } \\
\hline $\mathbf{1}(\mathbf{0 , 0})$ & 2,2500 & Transformados \\
$\mathbf{2}(\mathbf{0 , 5 )}$ & 5,1167 & $0,7003 \mathbf{B}$ \\
$\mathbf{3 ( 1 , 0 )}$ & 4,9667 & $1,5436 \mathbf{A}$ \\
$\mathbf{4 ( 1 , 5 )}$ & 4,5636 & $1,4105 \mathbf{A B}$ \\
$\mathbf{5}(\mathbf{2}, \mathbf{0})$ & 1,4500 & $1,3687 \mathbf{A B}$ \\
\hline
\end{tabular}

As letras iguais indicam que não há diferença significativa.

Como o observado em $P$. cincinnata, em tomateiros selvagens, Lycopersicon peruvianum, L. chilense e L. hirsutum, Peres et al. (2001) observaram alta capacidade de formação de gemas a partir de segmentos de raiz. As espécies Lycopersicon peruvianum e L. chilense apresentaram melhor resposta organogenética, produzindo maior número de gemas por explantes, 10,5 e 5,7, respectivamente, e em menor período de tempo. A formação de gemas ocorreu após 2-4 semanas em meio com zeatina. Do mesmo modo, em segmentos de raiz de caquizeiro "Fuyu", Biasi et al. (2002) também relataram alto potencial organogenético, em presença de TDZ e AIA. 


\subsubsection{PLÂNTULA}

Conforme explicado no item 2.2.2, neste ensaio, a repetição constituiurse de uma plântula por frasco, de tal forma que a resposta referente à capacidade organogênica não foi analisada estatisticamente por se tratar de freqüência do evento (Tabela 6), isto é, o resultado limitourse a resposta "sim" ou "não" do evento da organogênese.

Tabela 6. Freqüência de explantes (plântula) organogênicos de Passiflora cincinnata aos 28 e 56 dias em meio MS contendo diferentes doses de 6-BA e $5 \%$ de água de coco

\begin{tabular}{ccc}
\hline $\begin{array}{c}\text { Tratamentos } \\
\left(\mathbf{m g} \cdot \mathbf{L}^{-1} \mathbf{6 - B A}\right)\end{array}$ & $\mathbf{2 8}$ dias & $\mathbf{5 6}$ dias \\
\hline $1(0,0)$ & 0 & 13,33 \\
$2(0,5)$ & 93,33 & 100,00 \\
$3(1,0)$ & 80,00 & 93,33 \\
$4(1,5)$ & 70,00 & 86,66 \\
$5(2,0)$ & 70,00 & 80,00
\end{tabular}

As letras iguais indicam que não há diferença significativa.

Como nos discos foliares, na ausência de 6-BA a resposta organogênica foi nula aos 28 dias. Para as plântulas, a resposta foi muito baixa aos 56 dias. No entanto, todas as plântulas apresentaram a formação de gemas aos 56 dias quando cultivadas em meio contendo $0,5 \mathrm{mg} \cdot \mathrm{L}^{-1}$ de 6 BA.

Em relação ao número médio de gemas por plântula (Tabela 7) observa-se que não houve diferença significativa entre as concentrações de 6-BA testadas. Porém, na ausência do regulador vegetal o número médio foi significativamente menor.

Se compararmos os dados da tabela 5 e 7 observamos que, quando a raiz é isolada da parte aérea, o número de gemas formadas é maior. É interessante notar que em ambos explantes ocorreu a formação de gemas 
mesmo na ausência de 6-BA enquanto no disco foliar não ocorreu (Tabela 3).

Tabela 7. Número médio de gemas por explante (plântula) de Passiflora cincinnata submetidos aos 56 dias de cultura em meio MS contendo diferentes doses de 6 -BA e $5 \%$ de água de coco

\begin{tabular}{ccc}
\hline \multirow{2}{*}{ Tratamentos } & \multicolumn{2}{c}{ Gemas/explante } \\
(mg.L-1 $\mathbf{6 - B A})$ & Sem transformação & Transformados \\
\hline $\mathbf{1}(\mathbf{0 , 0})$ & 0,3200 & $0,2064 \mathbf{~ B}$ \\
$\mathbf{2}(\mathbf{0 , 5})$ & 3,8800 & $1,8878 \mathbf{A}$ \\
$\mathbf{3}(\mathbf{1}, \mathbf{0})$ & 4,8857 & $1,9871 \mathbf{A}$ \\
$\mathbf{4}(\mathbf{1 , 5})$ & 3,8933 & $1,6019 \mathbf{A}$ \\
$\mathbf{5}(\mathbf{2}, \mathbf{0})$ & 4,0133 & $1,7022 \mathbf{A}$ \\
\hline
\end{tabular}

Em Passiflora cincinnata ocorre a formação de gemas em raízes ex vitro (Passos, comunicação pessoal). De acordo com Peres e Kerbauy (2000) a capacidade de formar gemas caulinares em raízes ex vitro se reflete na competência para regeneração in vitro a partir deste tipo de explante (Peres et al., 2001). De fato, no presente estudo verificou-se a formação de gemas em segmentos de raízes e em raízes intactas da plântula. Na ausência do regulador, comparando a resposta do número de gemas formadas nas raízes das plântulas e aquela obtida quando a raiz foi segmentada, observa-se que com 0 isolamento da raiz a concentração hormonal endógena favoreceu a formação das gemas. A remoção da parte aérea parece promover o balanço auxina/citocinina favorável àformação das gemas. Estas duas fontes de explante e as respostas obtidas na ausência do regulador podem constituir um modelo interessante para estudos sobre 0 crescimento integrado entre caules e raízes. 


\subsection{Análises morfológicas}

\subsubsection{Disco foliar}

Através da análise visual, observou-se que os discos foliares do tratamento 1 , a partir do $14^{\circ}$ dia de cultura apresentaram alterações na coloração (Fig. 2): superfícies de corte apresentaram coloração amarelada e a região central leve escurecimento. Aos 35 dias de cultura observou-se 0 início da morte dos explantes os quais apresentavam consistência seca e coloração palha (Fig. 2).

No tratamento $2\left(0,5 \mathrm{mg} \cdot \mathrm{L}^{-1}\right.$ 6-BA), aos 14 dias de cultura notourse início da formação do calo nas superfícies de seccionamento dos explantes que ficaram levemente retorcidos. A partir do $21^{\circ}$ dia de cultura, observourse a formação de gemas nos calos (Fig.3). Em relação aos demais tratamentos, o tratamento 2 apresentou maior número de gemas formadas aos 28 dias de cultura.

Nos tratamentos 3 (1,0 mg.L ${ }^{-1}$ 6-BA) e 4 (1,5 mg. $\mathrm{L}^{-1}$ 6-BA) o início da formação do calo nas superfícies de seccionamento ocorreu ao $7^{\circ}$ dia de cultura. No $21^{\circ}$ dia de cultura, os explantes apresentaram aumento de tamanho e da massa de calo. A partir do $21^{\circ}$ dia de cultura observourse a formação de gemas nos calos (Fig.4 e 5), em Passiflora edulis f. flavicarpa a formação de gemas nos discos foliares apenas foi observada após 28 dias de cultura (Da Gloria et al. 1999).

O tratamento 5 (2,0 mg. $\mathrm{L}^{-1}$ 6-BA) apresentou maior formação de calos nas superfícies de corte, quando comparado aos demais tratamentos (Fig. 6). Conforme relatado no item 3.2.1, a formação de gemas foi significativamente menor sendo observada após 28 dias de cultura (Fig. 6).

Durante todo o período de cultura analisado, a origem das gemas nos tratamentos 2, 3, 4 e 5 foi indireta a partir do calo formado na superfície de seccionamento do explante como será ilustrado no item 3.4.1. 


\section{Disco foliar \\ Trat. 1 (0,0 $\mathrm{mg} / \mathrm{L}$ de 6-BA)}
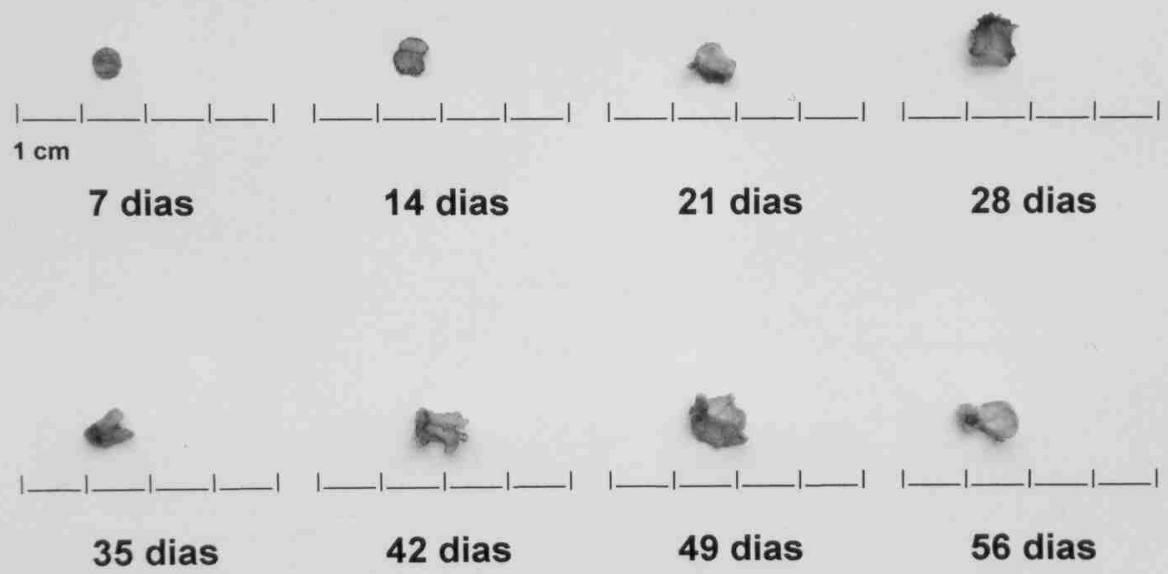

Figura 2 - Avaliação semanal do disco foliar submetido ao tratamento 1, no período de 8 semanas

\section{Disco foliar \\ Trat. 2 (0,5 mg/L de 6-BA)}
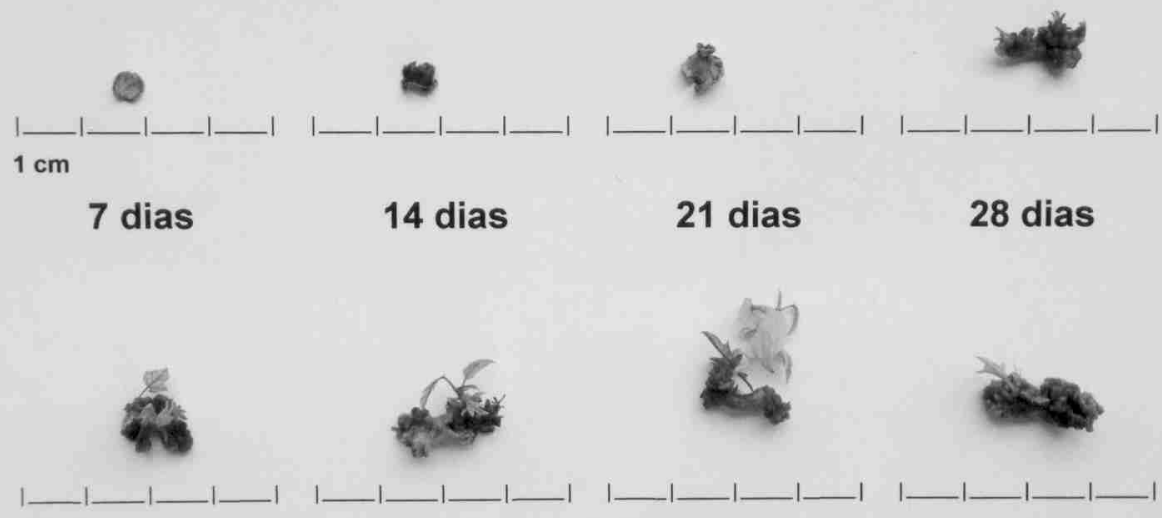

35 dias

42 dias

49 dias

56 dias

Figura 3 - $\quad$ Avaliação semanal do disco foliar submetido ao tratamento 2, no período de 8 semanas 


\section{Disco foliar \\ Trat. 3 (1,0 mg/L de 6-BA)}
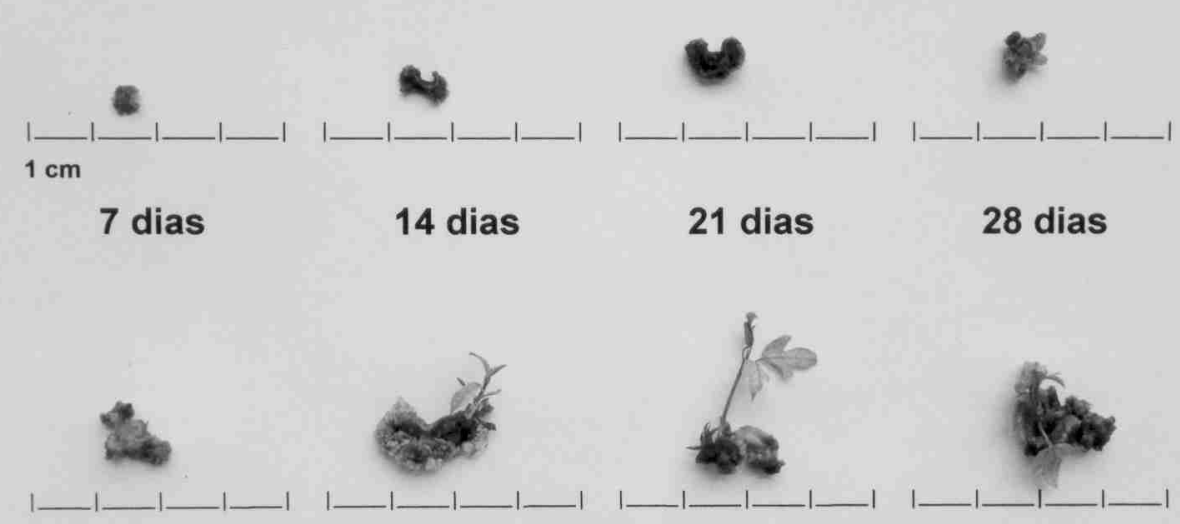

35 dias

42 dias

49 dias

56 dias

Figura 4 - Avaliação semanal do disco foliar submetido ao tratamento 3 , no período de 8 semanas

\section{Disco foliar \\ Trat. 4 (1,5 mg/L de 6-BA)}
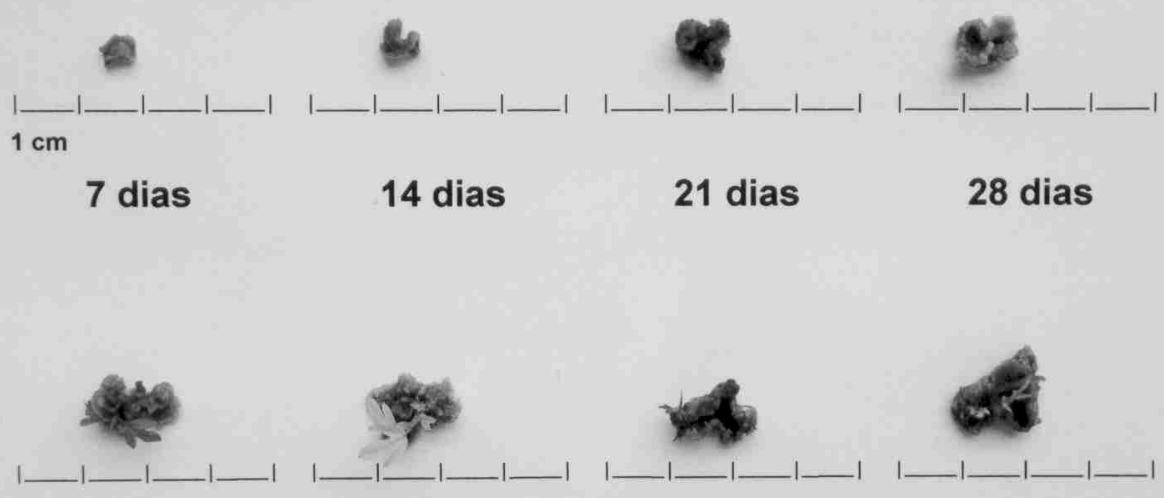

35 dias

42 dias

49 dias

56 dias

Figura 5 - $\quad$ Avaliação semanal do disco foliar submetido ao tratamento 4 , no período de 8 semanas 


\section{Disco foliar \\ Trat. 5 (2,0 mg/L de 6-BA)}
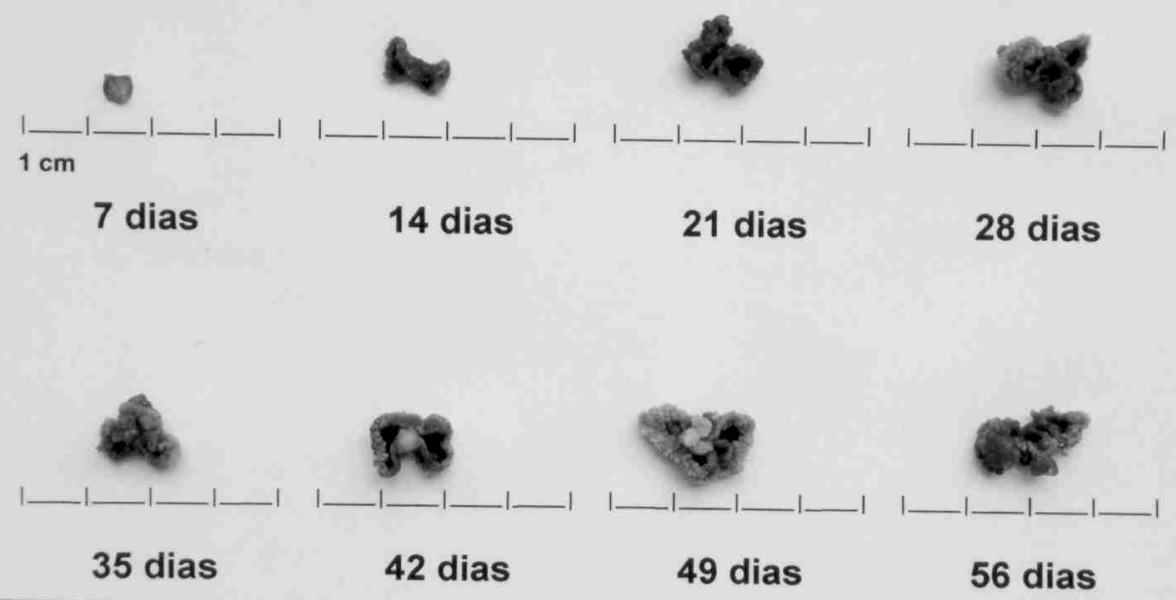

Figura 6 - Avaliação semanal do disco foliar submetido ao tratamento 5 , no período de 8 semanas 


\subsubsection{Segmento de raiz}

Os explantes submetidos ao tratamento 1 aos 7 dias de cultura apresentaram formação de gemas (20 \%), o que não foi observado no disco foliar. Duas plantas regeneradas a partir de segmento de raiz podem ser visualizadas na figura 13. A formação de gemas ocorreu com maior freqüência nas superfícies de corte e pequeno número nas regiões centrais dos explantes. Neste tratamento houve grande crescimento das raízes laterais (Fig. 7).

No tratamento $2\left(0,5 \mathrm{mg} \cdot \mathrm{L}^{-1}\right.$ 6-BA), pode-se observar a formação de gemas aos 7 dias de cultura. Aos 28 dias de cultura, 60\% dos explantes apresentaram formação de gemas, direta e indiretamente, nas superfícies de corte e regiões centrais dos explantes (Fig. 8). Notourse pequeno crescimento de raízes laterais, brancas e finas. A formação de gemas foi contínua.

Os tratamentos 3 (1,0 mg. $\mathrm{L}^{-1}$ 6-BA) e 4 (1,5 mg. $\mathrm{L}^{-1}$ 6-BA), nos primeiros dias de cultura, formaram calos na superfície de corte e estes apresentaram aspecto intumescido (Fig. 9 e 10). A formação de gemas foi observada aos 14 dias de cultura juntamente com inúmeros pontos verdes, que nas seções histológicas revelaram tratar-se de pontos de origem das futuras gemas. A partir dos 42 dias de cultura os explantes passaram a apresentar aspecto de "touceira" devido àproximidade entre as gemas (Fig. 11).

O tratamento 5 (2,0 mg. $\mathrm{L}^{-1}$ 6-BA), apresentou aos 7 dias de cultura formação de calos nas superfícies de corte e alteração na coloração em $20 \%$ dos explantes, verde para marrom claro. Houve pequena formação de gemas a partir do $14^{\circ}$ dia de cultura, estas sempre nas extremidades das raízes (Fig. 12).

Nos segmentos de raiz, a formação de gemas ocorreu direta e indiretamente, tanto na superfície do explante como nas extremidades de raízes laterais conforme será descrito no item 3.4. 


\section{Segmento de raiz Trat. 1 (0,0 mg/L de 6-BA)}
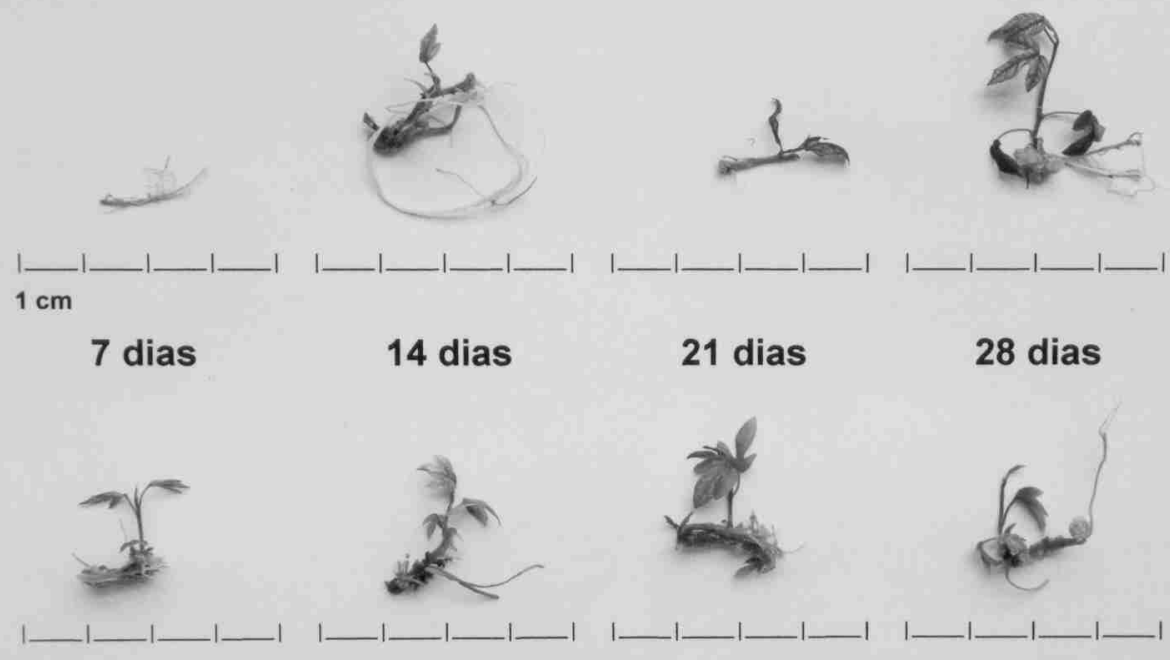

35 dias

42 dias

49 dias

56 dias

Figura 7 - Avaliação semanal do segmento de raiz submetido ao tratamento 1 , no período de 8 semanas

\section{Segmento de raiz Trat. 2 (0,5 mg/L de 6-BA)}

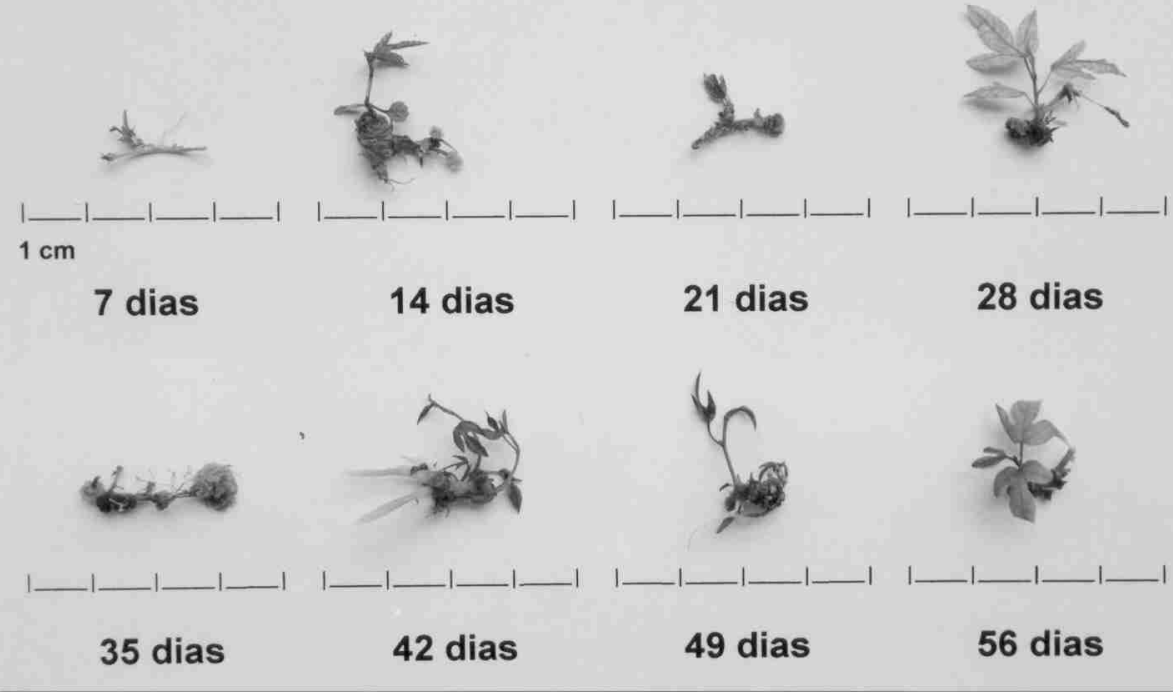

Figura 8 - $\quad$ Avaliação semanal do segmento de raiz submetido ao tratamento 2, no período de 8 semanas 


\section{Segmento de raiz}

\section{Trat. 3 (1,0 mg/L de 6-BA)}
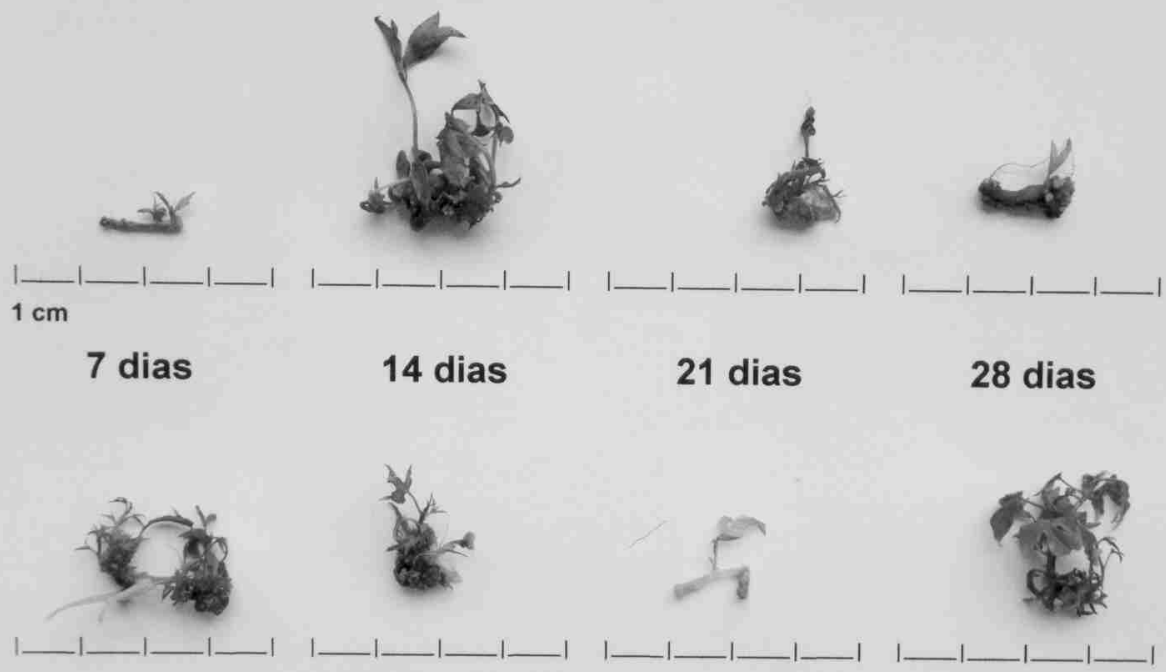

35 dias

42 dias

49 dias

56 dias

Figura 9 - Avaliação semanal do segmento de raiz submetido ao tratamento 3 no período de 8 semanas

\section{Segmento de raiz Trat. 4 (1,5 mg/L de 6-BA)}
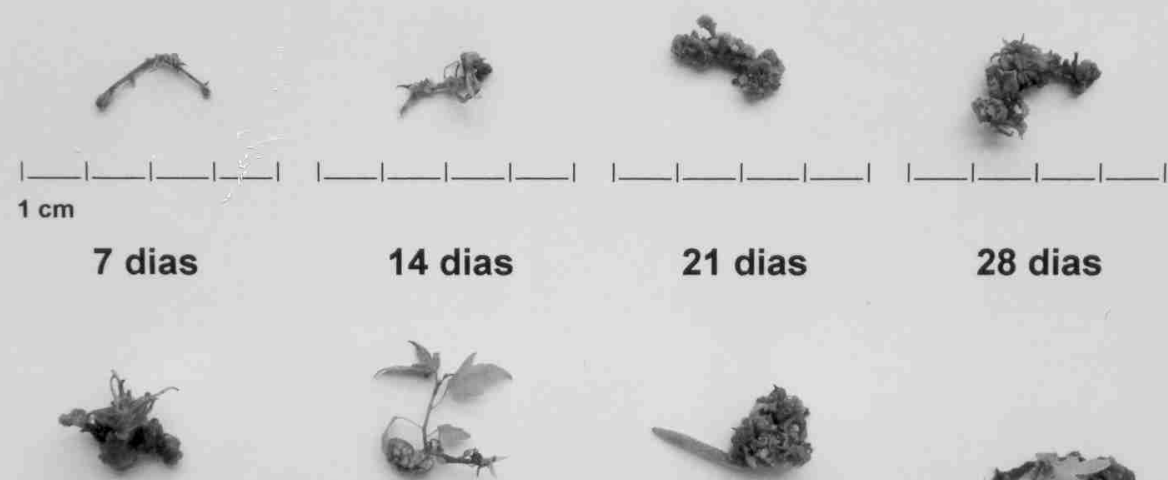

35 dias

42 dias

49 dias

56 dias

Figura 10 - Avaliação semanal do segmento de raiz submetido ao tratamento 4 , no período de 8 semanas 


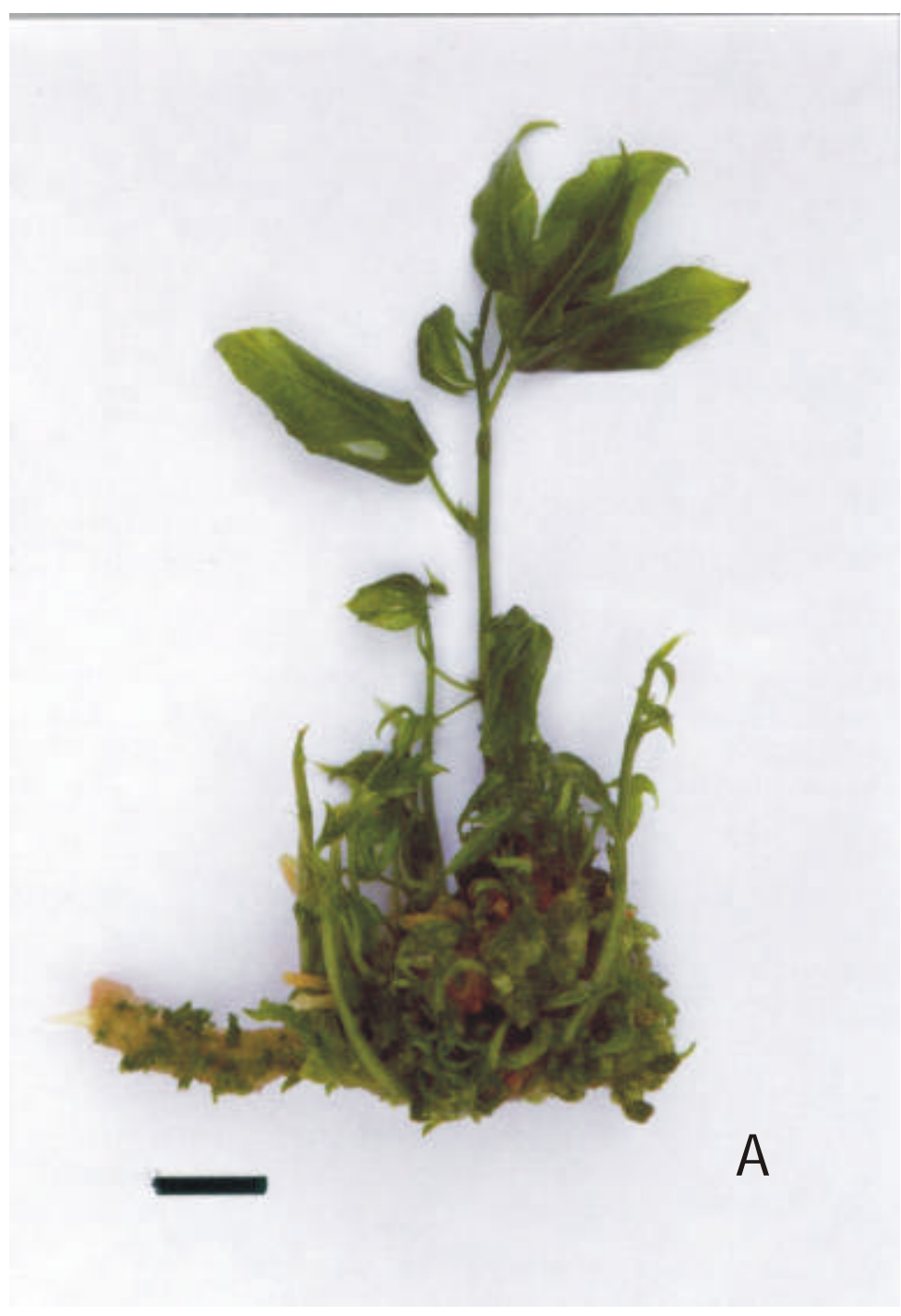

Figura 11 - Segmento de raiz aos 42 dias de cultura, submetido ao meio MS contendo 1,0 mg. $\mathrm{L}^{-1}$ de 6-BA e água de coco (5\%). Barra $=1,5 \mathrm{~cm}$ 


\section{Segmento de raiz Trat. 5 (2,0 mg/L de 6-BA)}
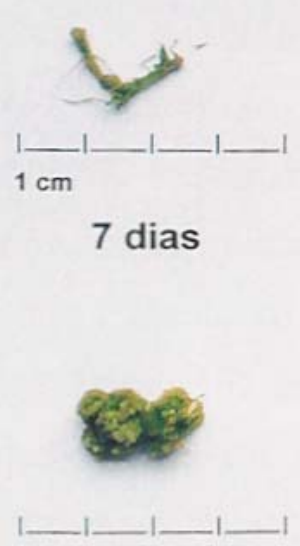

35 dias

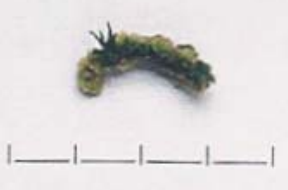

14 dias
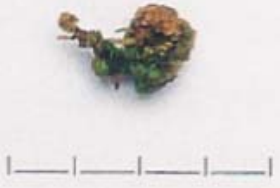

42 dias
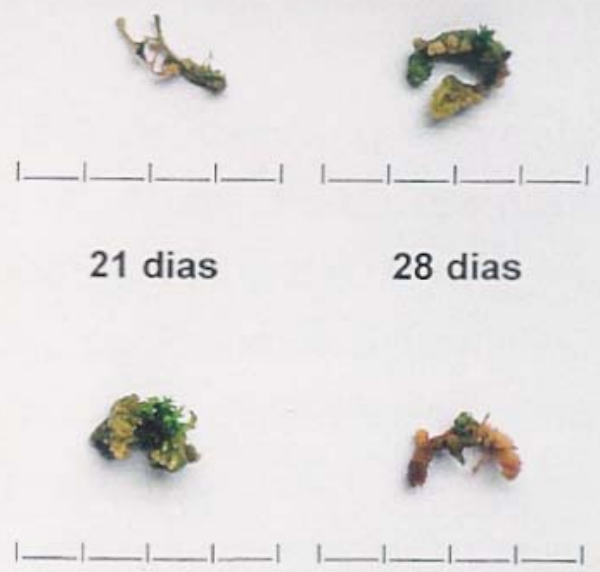

49 dias

56 dias

Figura 12 - Avaliação semanal do segmento de raiz submetido ao tratamento 5 no período de 8 semanas
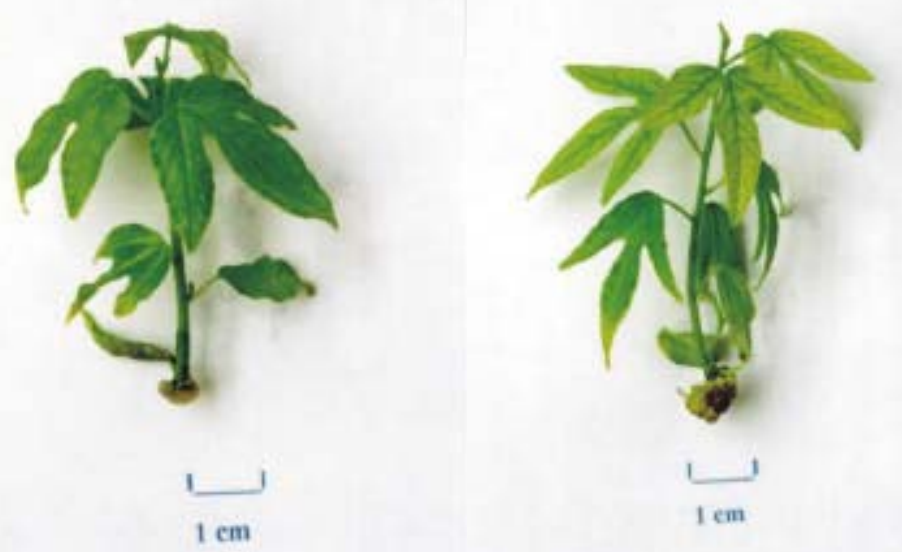

A

B

Figura 13 - Plantas regeneradas a partir de segmento de raiz submetido ao tratamento 1 (0,0 mg.L-16-BA) 


\subsubsection{Plântula}

Os aspectos visuais referentes ao ensaio com o explante plântula estão ilustrados nas figuras 14 a 18, nas quais a parte aérea da plântula foi removida para a montagem das pranchas.

No tratamento 1, após os 42 dias de cultura, duas repetições apresentaram formação de gemas (Fig. 14). A raiz primária das plântulas apresentou crescimento normal e suas raízes laterais eram brancas e finas.

No tratamento 2 (0,5 mg. $\mathrm{L}^{-1}$ 6-BA), aos 7 dias de cultura, $60 \%$ dos explantes formaram gemas nas raízes primárias e laterais das plântulas, preferencialmente na porção proximal destas (Fig. 15). Com 14 dias de cultura todas as repetições apresentaram formação de gemas. Na figura 20 podemos observar organogênese direta a partir da raiz primária da plântula de Passiflora cincinnata aos 28 dias de cultura em meio MS com 0,5 mg. $\mathrm{L}^{-1}$ de 6-BA e água de coco (5\%).

No tratamento 3 (1,0 mg. $\mathrm{L}^{-1}$ 6-BA), aos 21 dias de cultura, 50\% dos explantes apresentaram formação de gemas nas raízes primárias das plântulas (Fig. 16), preferencialmente na porção proximal destas.

Os tratamentos 4 (1,5 mg. $\mathrm{L}^{-1}$ 6-BA) e 5 (2,0 mg.L ${ }^{-1}$ 6-BA) com 7 dias de cultura apresentaram número semelhante de explantes com formação de gemas (Fig. 17 e 18), mas diferiram no número de gemas formadas por explante, tendo o tratamento 4 melhor resposta. Com 28 dias de cultura, $60 \%$ dos explantes apresentaram formação de gemas, também distribuídas na porção proximal da raiz primária da plântula. $\mathrm{O}$ tratamento 4 devido à formação contínua de novas gemas apresentou aspecto de "touceira" (Fig. 17). Na figura 19 observa-se uma plântula com 56 dias de cultura, em meio MS acrescido de 2,0 mg. $\mathrm{L}^{-1}$ de 6 -BA e água de coco $5 \%$. 


\section{Trat. 1 (0,0 $\mathrm{mg} / \mathrm{L}$ de $6-\mathrm{BA})$}
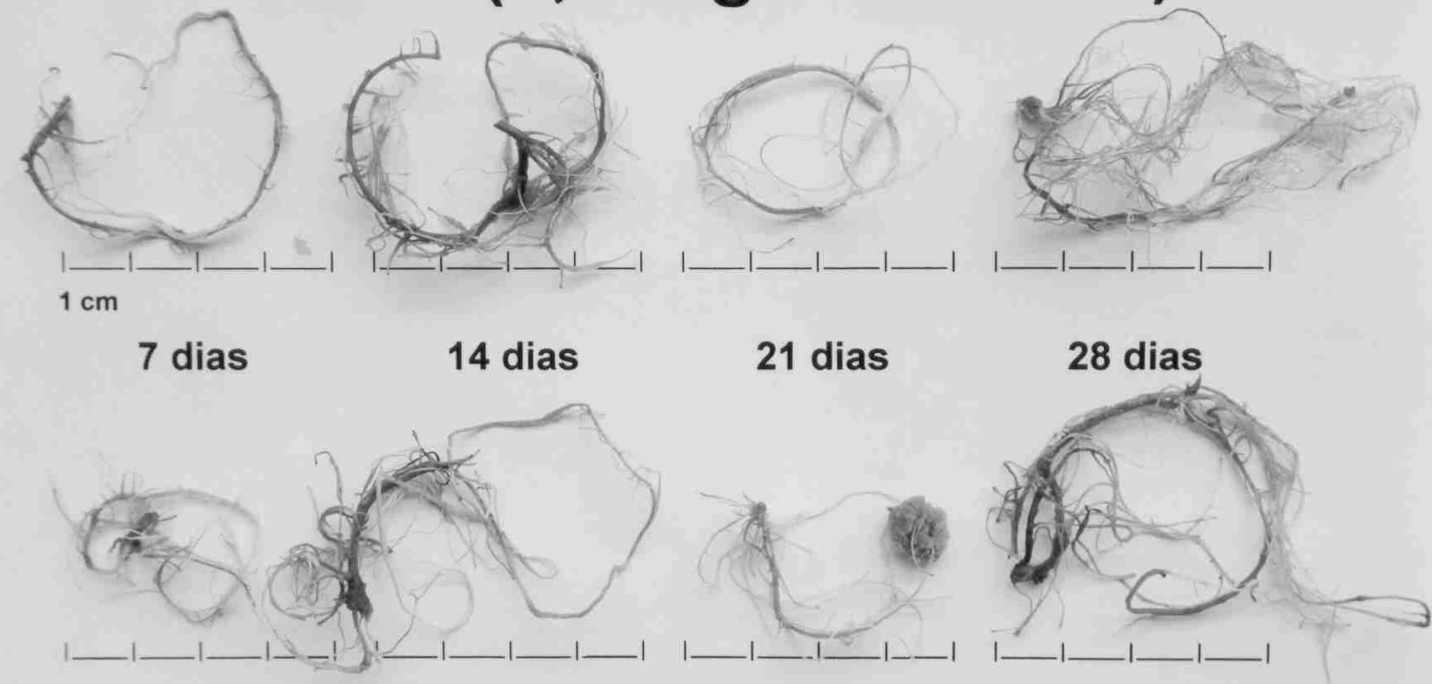

35 dias

42 dias

49 dias

56 dias

Figura 14 - Avaliação semanal do explante plântula submetido ao tratamento 1, no período de 8 semanas; a parte aérea foi removida para a montagem da prancha

\section{Plântula \\ Trat. $2(0,5 \mathrm{mg} / \mathrm{L}$ de $6-\mathrm{BA})$}

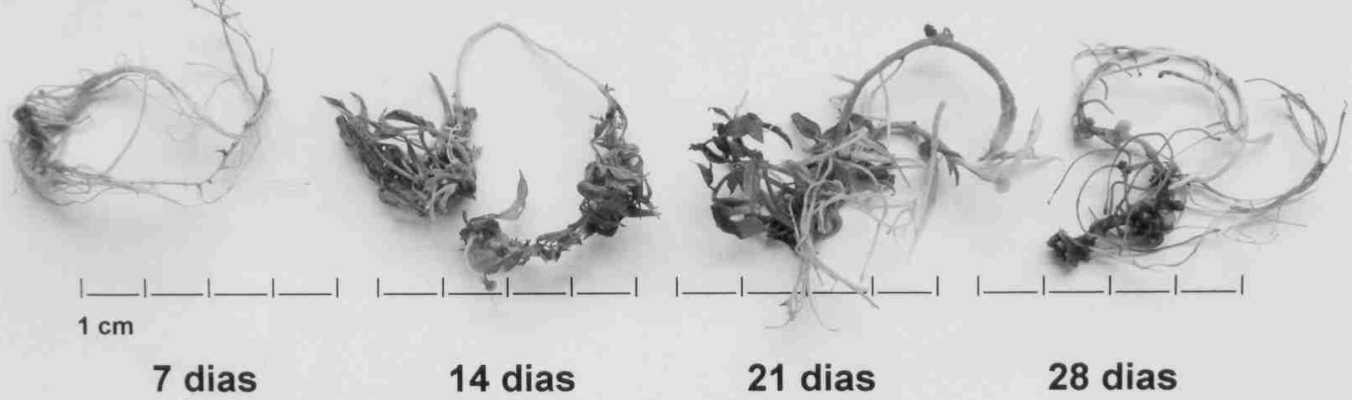

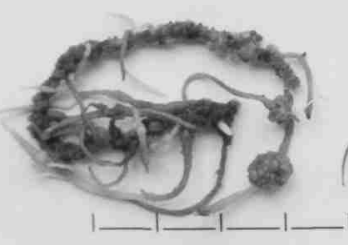

35 dias

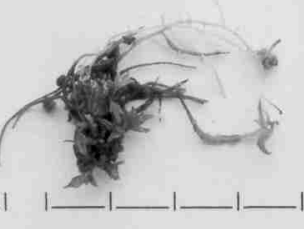

42 dias

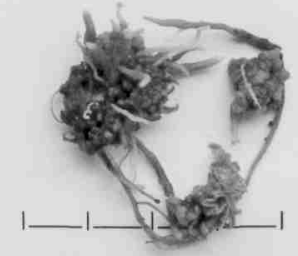

49 dias

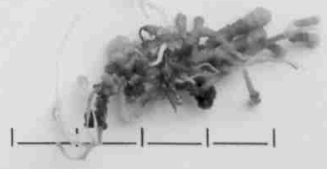

56 dias

Figura 15 - Avaliação semanal do explante plântula submetido ao tratamento 2, no período de 8 semanas; a parte aérea foi removida para a montagem da prancha 


\section{Plântula \\ Trat. 3 (1,0 mg/L de 6-BA)}

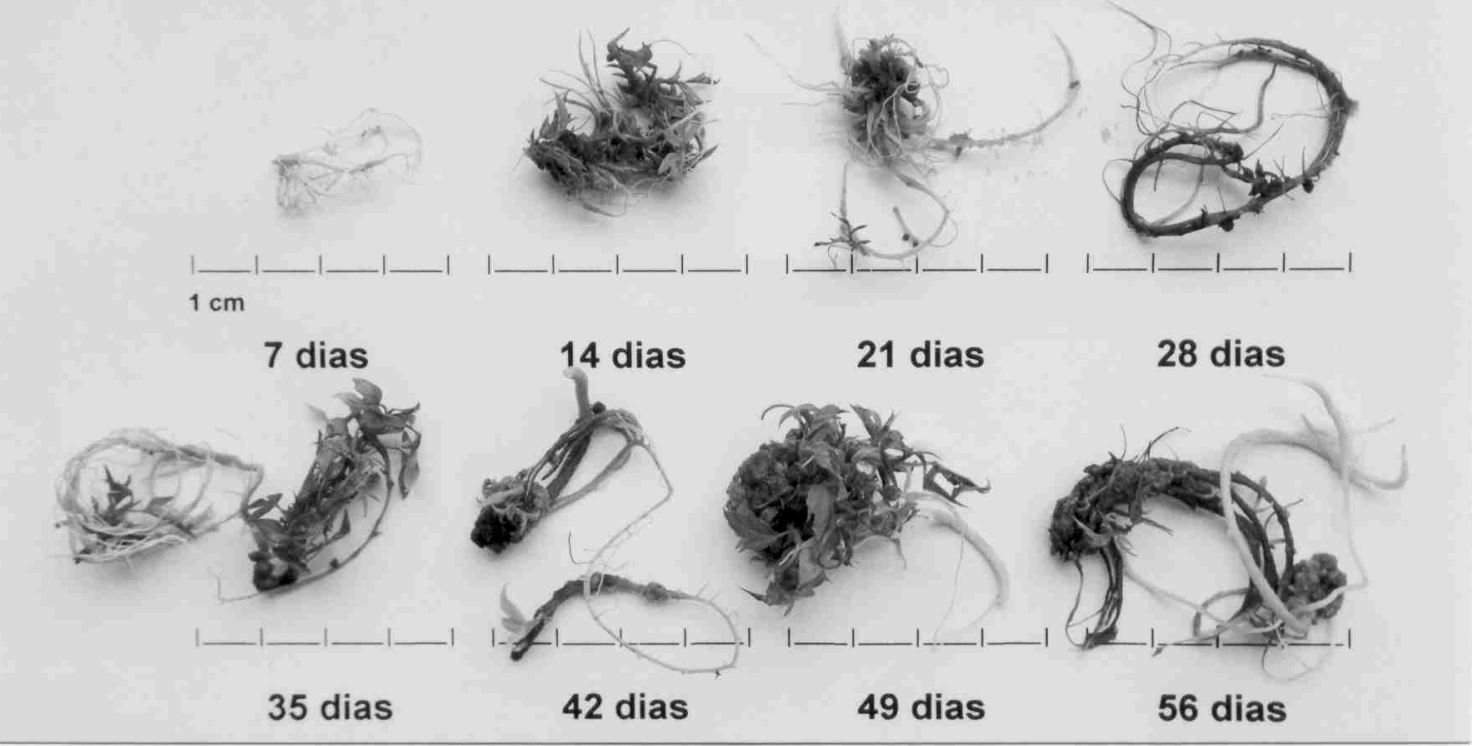

Figura 16 - Avaliação semanal dos explante plântula submetido ao tratamento 3, no período de 8 semanas; a parte aérea foi removida para a montagem da prancha

\section{Plântula \\ Trat. 4 (1,5 mg/L de 6-BA)}
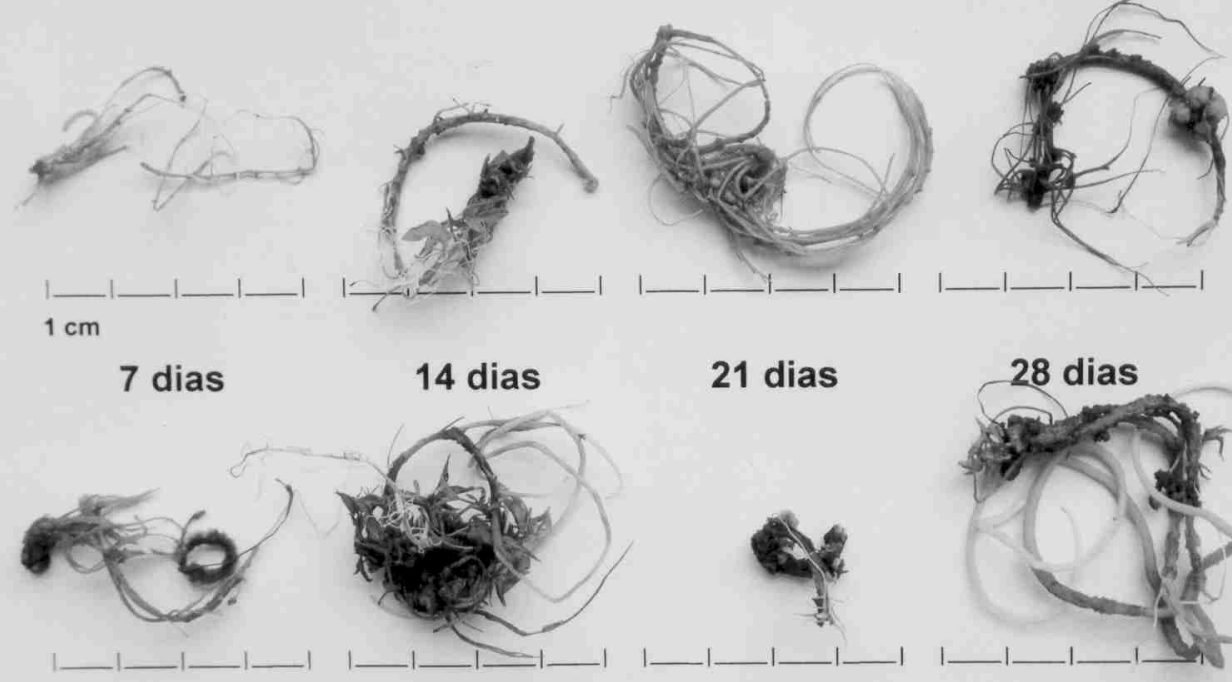

21 dias

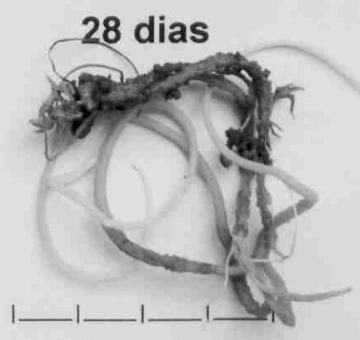

35 dias

42 dias

49 dias

56 dias

Figura 17 - Avaliação semanal do explante plântula submetido ao tratamento 4, no período de 8 semanas; a parte aérea foi removida para a montagem da prancha 


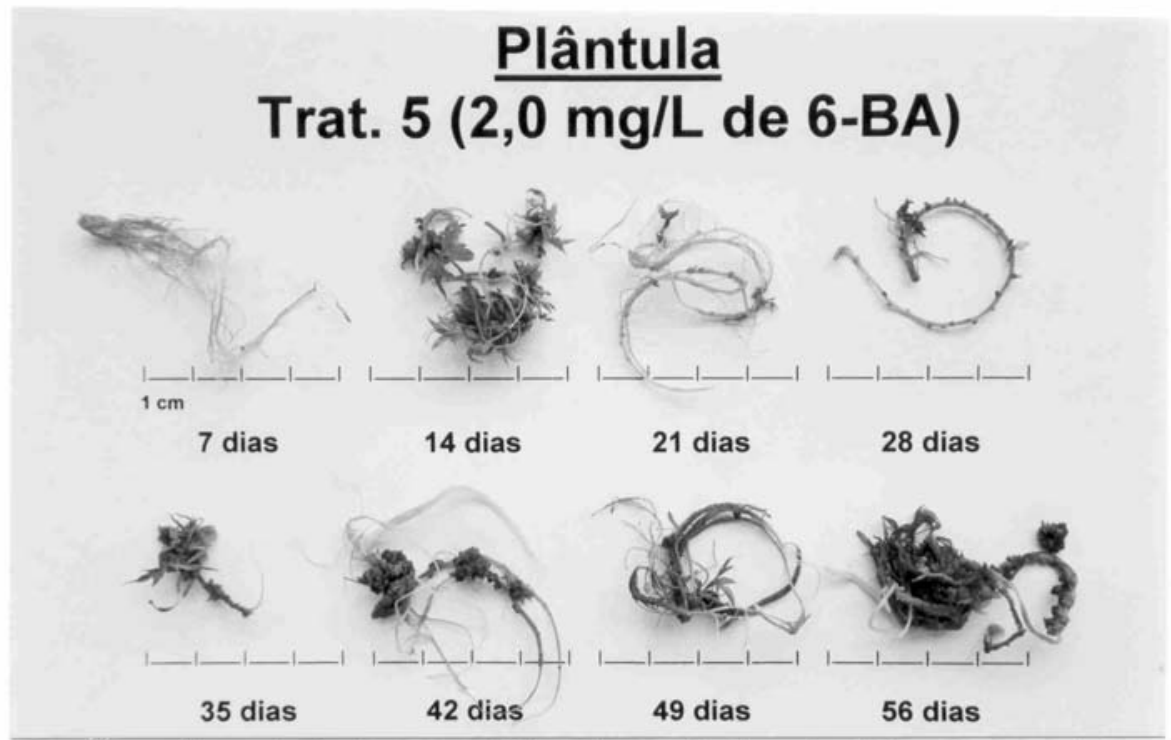

Figura 18 - Avaliaçăo semanal do explante plântula submetido ao tratamento 5 , no período de 8 semanas; a parte aérea foi removida para a montagem da prancha 


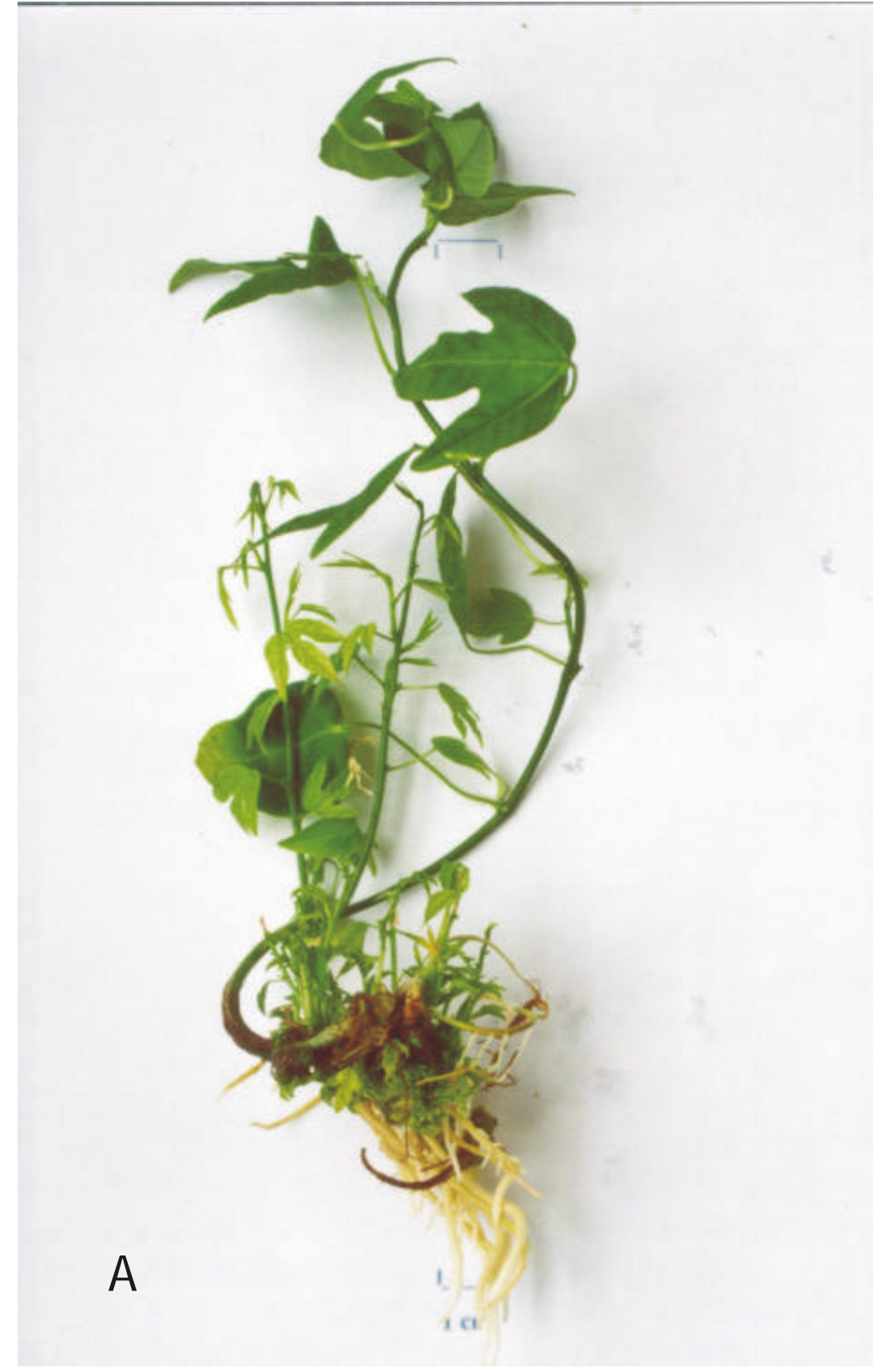

Figura 19 - Plântula com 56 dias de cultura, em meio MS contendo 2,0 mg. $\mathrm{L}^{-1}$ de 6-BA e água de coco (5\%) 


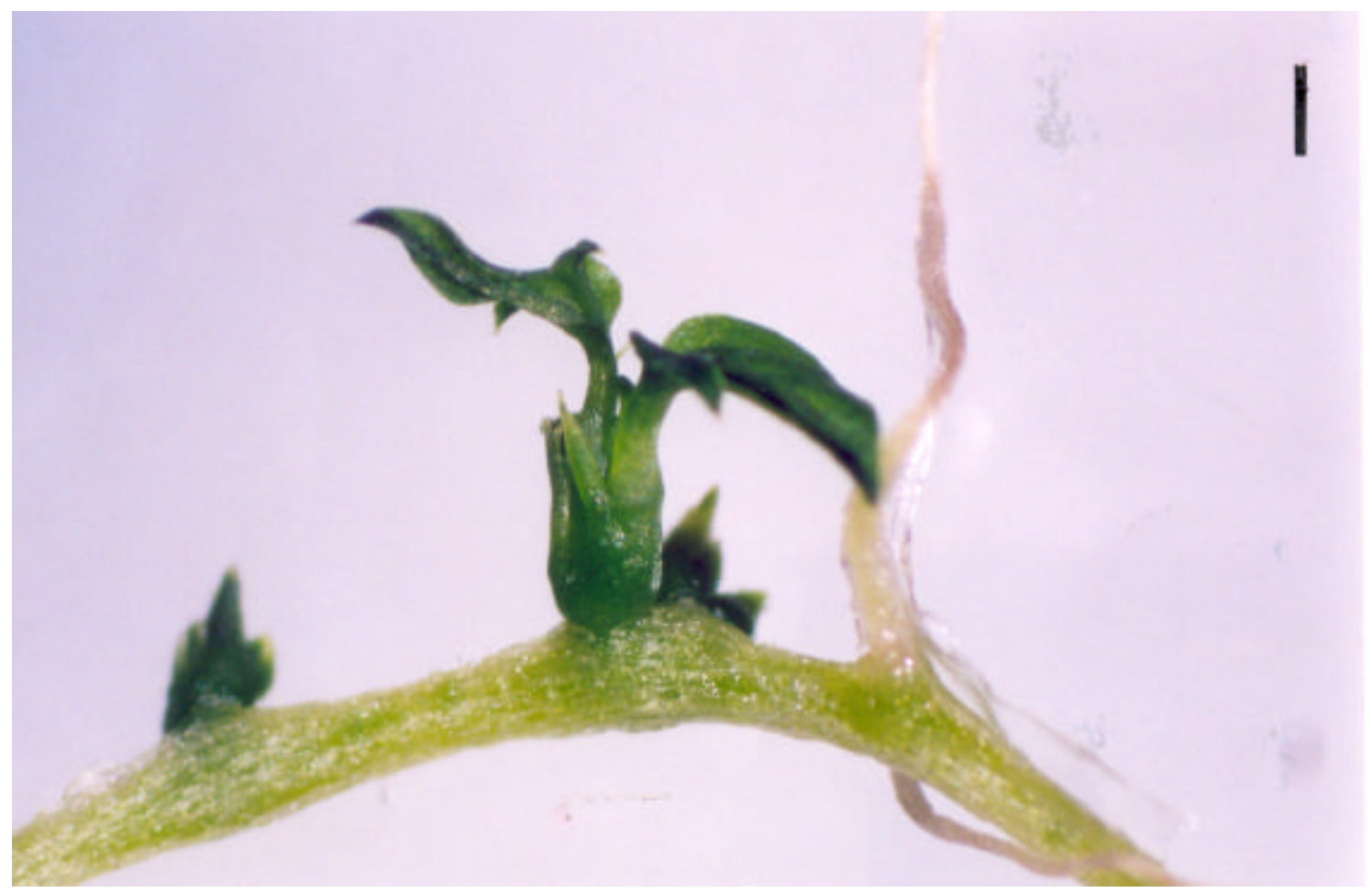

Figura 20 - Organogênese direta a partir da raiz primária do explante plântula de Passiflora cincinnata aos 28 dias em meio contendo $0,5 \mathrm{mg} \cdot \mathrm{L}^{-1}$ de 6 BA e água de coco (5\%) 


\subsection{Análises anatômicas}

As análises anatômicas permitiram descrever o processo de formação das gemas para os três explantes.

\subsubsection{Disco foliar}

Nos discos foliares a formação das gemas ocorreu via organogênese indireta, a partir do calo resultante de proliferações celulares no parênquima clorofiliano (Apêndice 1).

O início das alterações anatômicas pôde ser observado aos 14 dias de cultura. Em algumas regiões do parênquima clorofiliano, as células sofreram divisões periclinais e anticlinais (Apêndice 1 B), que se intensificaram durante o tempo de cultura, formando calo ao longo da superfície do explante (Apêndices 1 A e 2 A). A origem do calo pode ser bem visualizada no apêndice $1 \mathrm{~B}$ na qual é possível verificar um setor com a estrutura foliar pouco alterada (à esquerda) e um setor com a estrutura foliar bastante alterada (à direita). A estrutura foliar não alterada apresenta as epidermes superior e inferior íntegras, o mesofilo dorsiventral diferenciado em parênquima paliçádico unisseriado e parênquima lacunoso com três camadas de células. Por sua vez, na estrutura foliar alterada, ocorre aumento pronunciado no número de camadas de células do mesofilo (19 camadas) levando à descontinuidade das epidermes, em especial, da epiderme inferior. Esta proliferação celular do parênquima clorofiliano caracteriza o início da formação do calo.

Nas camadas superficiais do calo, algumas regiões apresentaram intensas atividades mitóticas, formando áreas meristemáticas que deram origem aos meristemóides, sendo possível verificar pequenas protrusões na superfície do calo (Apêndices 1 A e 2 A). Os meristemóides são constituídos por células pequenas com citoplasma denso e núcleo e nucléolo evidente (Apêndices 1 C e 2 B-C), e estes indicam o início da diferenciação das gemas caulinares (Apêndices 2 D e 3 A-B). Em Bauhinia forficata Link, Melo 
et al. (2000) relataram o processo similar de formação dos meristemóides, somente diferindo o tecido de origem dos calos. Em P. edulis f. flavicarpa, Appezzato-da-Glória et al. (1999) observaram as mesmas alterações anatômicas, sob condições de luz e 1,0 mg. $\mathrm{L}^{-1}$ de BAP, em explantes foliares, cujas divisões celulares se iniciaram aos 14 dias de cultura nas camadas subepidérmicas, formando meristemóides. Segundo os autores, aos 28 dias, ocorreu a desorganização do sistema vascular na nervura central, resultado da intensa atividade meristemática, e a formação da gema caulinar.

Diversos estágios de desenvolvimento foram observados em um mesmo explante, devido à contínua e simultânea formação de calos e gemas (Apêndices 2 A e 3 A). O processo assincrônico da organogênese in vitro pode ser devido à aquisição de competência e determinação das células em estágios diferenciados. A falta de sincronia no processo organogênico também foi relatado para a espécie $P$. edulis f. flavicarpa (Dornelas \& Vieira, 1994; Appezzato-da-Glória et al., 1999; Biasi et al. 2000).

Durante o desenvolvimento da gema, notourse a formação de nódulos vasculares próximos àsua base, estabelecendo a conexão vascular com o calo (Apêndice $3 \mathrm{C}$ ). A presença de nódulos vasculares na base de gemas promovendo a conexão vascular destas com o tecido de origem já havia sido descrita por Alves (1999) em Glycine max. 


\subsubsection{Segmento de raiz e plântula}

A organogênese in vitro em $P$. cincinnata a partir do segmento de raiz pode ocorrer direta e indiretamente. Na organogênese direta (Apêndice 6) nos segmentos radiculares apresentou duas origens distintas de acordo com a fase de desenvolvimento da raiz (Apêndices 4 e 5). No início do crescimento secundário (Apêndice 4 B) na área de saída da gema caulinar a raiz apresenta a epiderme e o córtex rompidos. No apêndice $4 \mathrm{C}$, observa-se em detalhe a camada da endoderme rompida e o periciclo logo abaixo desta em divisão. A gema caulinar surge endogenamente a partir do periciclo e a conexão vascular entre a gema e a raiz ocorre acropetamente. $O$ restante do cilindro vascular é constituído do floema, câmbio vascular e xilema. $\mathrm{Na}$ estrutura secundária mais avançada (Apêndice 5) observa-se que o meristemóide que se desenvolverá na gema caulinar origina-se no câmbio vascular (Apêndice 5 A-C).

$\mathrm{Na}$ organogênese indireta (Apêndice 6) o calo formava-se preferencialmente nas extremidades da raiz, sendo que as gemas eram observadas na superfície do calo. Em alguns setores da raiz, as células do periciclo sofreram sucessivas divisões formando o calo (Apêndice 6 B). Nas camadas periféricas do calo resultante da proliferação do periciclo as células sofreram diferenciações e deram origem aos meristemóides (Apêndice 6 BC) que se desenvolveram em gemas caulinares.

Nas raízes das plântulas (Apêndice 7 A), a formação de gemas ocorreu via direta, e a origem foi semelhante à observada para o segmento de raiz.

A origem a partir do periciclo foi observada nas raízes com início do crescimento secundário. Em algumas regiões do periciclo, as células sofreram divisões periclinais e anticlinais, originando os meristemóides (Apêndice 7 B-C). A origem cambial também foi observada nas raízes das plântulas, aqui não documentada para evitar repetição.

Diferente do relatado para $P$. cincinnata, em Curcuma zedoaria (Melo et al., 2001), a organogênese indireta foi observada a partir de 
segmentos de raiz, mas as divisões celulares para a formação do calo ocorreram a partir do parênquima cortical. Do mesmo modo, Peres et al. (2001) observaram em análises anatômicas de tomateiros selvagens (Lycopersicon peruvianum, L. chilense e L. hirsutum) cultivados in vitro, a formação de gemas a partir de raízes, a qual também ocorreu direta e indiretamente, dependendo do genótipo utilizado. A formação indireta da gema ocorreu juntamente com a formação de calo a partir do parênquima cortical, via meristemóides, nas camadas periféricas. Entretanto, a formação da gema a partir do calo formado ocorreu de maneira similar ao observado em $P$. cincinnata, nas camadas periféricas do calo. 


\section{CONCLUSÕES}

A organogênese em Passiflora cincinnata Mast ocorre direta e indiretamente dependendo do explante e/ou tempo de cultivo in vitro. É um processo assincrônico e o regulador vegetal 6-BA favorece o processo sendo imprescindível a sua adição para a resposta organogênica do disco foliar nas condições de cultivo estudadas. 


\section{REFERÊNCIAS BIBLIOGRÁFICAS}

AGRA, M.F.; LOCATELLI, E.; ROCHA, E. A.; BARACHO, G.S.; FORMIGA, S.C. Plantas medicinais nos Cariris Velhos, Paraíba, Parte II: subclasses Magnoliidae, Caryophyllidae, Dilleniidae e Rosidae. Revista Brasileira de Farmácia, v. 3, n.7, p. 97-102. 1996.

Al-KHAYRI, J. M.; HUANG, F. H; MOULORK, T. E.; BUSHARAR. Spinash tissue culture improved with coconut water. HortScience, v. 27, p.357358, 1992.

ALVES, A. C. Estudos anatômicos da organogênese in vitro de soja e otimização do processo de transformação via Agrobacterium tumefaciens, Piracicaba, 1999. 107p. , Dissertação (Mestrado) - Escola Superior de Agricultura "Luiz de Queiroz", Universidade de São Paulo.

BARBOSA, L. V. Citologia de híbridos somáticos de Passiflora spp. obtidos por fusão de protoplasto. Piracicaba, 1998. 127p. Tese (Doutorado) Escola Superior de Agricultura 'Luiz de Queiroz", Universidade de São Paulo.

BIASI, L. A.; FALCO, M. C.; RODRIGUEZ, A. P. M.; MENDES, B. M. J. Organogenesis from internodal segments of yellow passion fruit. Scientia Agricola, v. 57, n. 4, p. 661-665, out./dez. 2000. 
BURRITT, D.; LEUNG, D.W.M. Organogenesis in cultured petiole explants of Begoniax erythrophylla the timing and specificity of the inductive stimuli. Journal of Experimental Botany, v. 47, p.557-567, 1996.

CHRISTIANSON, M.L.; WARNICK, D.A. Organogenesis in vitro as a developmental process. HortScience, v. 23, p. 515-519, 1988.

CONEGLIAN, R. C. C.; ROSSETO, C. A. V.; SHIMUZU, M. K.; VASCONCELOS, M. A. S. Germinação de sementes de Passiflora alata em substrato umedecido com soluções de ácido giberélico. Revista Brasileira de Fisiologia Vegetal, v. n. 11, p. 47, 1999. Suplemento. / Apresentado ao $7^{0}$ Congresso Brasileiro de Fisiologia Vegetal, junho de 1999-Resumo/

DORNELAS, M.C.; VIEIRA, M.L.C. Tissue culture studies on species of Passiflora. Plant Cell Tissue and Organ Culture, v. 36, p. 211-217, 1994.

FERREIRA, M. E.; CALDAS, L. S.; PEREIRA, E. A. Aplicações da cultura de tecidos no melhoramento genético de plantas. In: TORRES, A. C.; CALDAS, L. S.; BUSO, J. A. (Ed.). Cultura de tecidos e transformação genética de plantas. Brasília: EMBRAPA, 1998. v. 1, p. 21-43.

FNP CONSULTORIA \& COMÉRCIO AGRIANUAL - 2002: anuário estatístico da agricultura brasileira. São Paulo, p. 402-408: Maracujá.

HALL, R. M.; DREW, R. A.; HIGGINS, C. M.; DIETZGEN, R. G. Efficient organogenesis of an Australian passionfruit hybrid (Passiflora edulis $x$ Passiflora edulis var. flavicarpa) suitable for gene delivery. Australian Journal Botany. v. 48, p. 673-680, 2000. 
HICKS, G. S. Shot induction and organogenesis in vitro: a developmental perspective. In Vitro Cell Developmental Biology, v.30, p.10-15, 1994.

KANTHARAJAH, A.S.; DODD, W. A. In vitro micropropagation of Passiflora edulis (purple passionfruit). Annals of Botany, v.65, p.337-339,1990.

KARNOVSKY, M.J. A formaldehyde-glutaraldehyde fixative of high osmolality for use in electron microscopy. Journal of Cell Biology v.27, p. 137-138. 1965.

KERBAUY, G. B. Competência e determinação celular em cultura de células e tecidos de plantas. In: TORRES, A. C.; CALDAS, L. S.; BUSO, J. A (Ed.). Cultura de tecidos e transformação genética de plantas. Brasília: CBAB;EMBRAPA, 1999. v. 2, p. 519-531.

KOORNNEEF, M.; HANHART, C. J.; MARTINELLI, L. A genetic analysis of cell culture traits in tomato. Theoretical and Applied Genetics. v. 74, p. 633-641, 1987.

KOORNNEEF, M.; BADE, J.; HANHART, C. J.; HORSMAN, K.; SCHEL, J.; SOPPE, W.; VERKEK, R.; ZABEL, P. Characterization and mapping of a gene controlling shoot regeneration in tomato. The Plant Journal, v. 3, p. 131-141, 1993.

LAKSHMANAM, P.; NG SK; LOH CS, GOH CJ. Auxin, cytokinin and ethylene differentially regulate specific developmental states associated with shoot bud morphogenesis in leaf tissues of mangosteen (Garcinia mangostana L.) cultured in vitro. Plant Cell Physiology, v. 38, n. 1, p. 59-64, 1997. 
LAPARRA, H.; BURRUS, M.; HUNOLD, R.; DAMM, B.; BRAVO-ANGEL, A. M.; BRONNER, R.; HAHNE, G. Expression of foreign genes in sunflower (Helianthus annus L.): evaluation of three gene transfer methods. Euphytica, v.85, p.63-74, 1995.

MELETTI, L. M. M. Caracterização agronômica de progênies de maracujá amarelo (Passiflora edulis f. flavicarpa Degener). Piracicaba, 1998. 92 p. Tese- (Doutorado) - Escola Superior de Agricultura Luiz de Queiroz", Universidade de São Paulo.

MELO, A. L. Métodos de quebra de dormência, e de armazenamento de sementes, e aspectos da obtenção de mudas de maracujá suspiro (Passiflora nitida H. B. K.). Jaboticabal, 1999. 95 p. Tese (Doutorado) Faculdade de Ciências Agrárias e Veterinárias, Universidade Estadual Paulista "Júlio de Mesquita Filho".

MELO, M. O.; MELO, M.; APPEZZATO-DA-GLÓRIA, B. Bahuinia forficata Link shoot regeneration: histological analysis of organogenesis pathway. Brazilian Archives of Biology and Technology, v. 43, n. 4, p. 431-436, 2000.

MELO, M. O.; MELO, M.; APPEZZATO-DA-GLÓRIA, B. Histological of the callogenesis and organogenesis from root segments of Curcuma zedoaria Roscoe. Brazilian Archives of Biology and Technology, v. 44, p. 197203, 2001.

MERCIER, H.; SOUZA, B. M.; J. E.; HAMASAKI, R. M.; SOTTA, B. Endogenous auxin and cytokinin associated with shoot formation in leaves of pineaple cultured in vitro. Brazilian Archives of Biology and Technology, v. 15, n. 2, p. 107-112, 2003. 
MONTEIRO, A. C. B; RODRIGUEZ, A. P. M., MENDES, B. M. J. Organogênese in vitro de maracujá amarelo (Passiflora edulis $\mathrm{f}$. flavicarpa) a partir de discos de folha. In: SIMPÓSIO DE INICIAÇÃO CIENTÍFICA DA UNIVERSIDADE DE SÃO PAULO, 4., Piracicaba, 1996. Resumos. São Paulo: USP, 1996. v. 1, p. 417.

MONTEIRO, A. C. B. Cultivo in vitro de três espécies do gênero Passiflora. Piracicaba, 2000. 82 p. Dissertação (Mestrado) - Escola Superior de Agricultura “Luiz de Queiroz”, Universidade de São Paulo.

MONTEIRO, A. C. B; NAKAZAWA, G. T.; MENDES, B. M. J.; RODRIGUEZ, A. P. M. Regeneração in vitro de Passiflora suberosa a partir de discos foliares. Scientia Agricola, v. 57, n.3, p. 571-573, 2000.

MURASHIGE, T.; SKOOG, F. A revised medium for rapid growth and bioassays with tobacco tissue cultures. Physiologia Plantarum, v.15, p.473-497, 1962.

NUNES, T. S.; QUEIROZ, L. P.. A família Passifloraceae na Chapada Diamantina, Bahia, Brasil. Sitientibus Série Ciências Biológicas, v.1, p.33-46, 2001.

PASSOS, I. R. S. Comportamento in vitro em Vitis spp e em Passiflora nitida H. B. K.. Piracicaba, 1999. 112 p. Tese (Doutorado) - Escola Superior de Agricultura "Luiz de Queiroz", Universidade de São Paulo.

PERES, L. E. P.; KERBAUY, G. B. High cytokinin accumulation following root tip excision changes the endogenous auxin-to-cytokinin ratio during rootto-shoot conversion in Catasetum fimbriatum Lindl. (Orchidaceae). Plant Cell Report, v. 18, p. 1002-1006,1999. 
PERES, L. E. P.; KERBAUY, G. B. Controle hormonal do desenvolvimento de raízes. Universa, v.8, p. 181-185, 2000.

PERES, L. E. P.; MORGANTE, P. G.; VECHI, C.;A .; KRAUS, J. E.; VAN SLUYS, M-A. Shoot regeneration capacity from roots and transgenic hairy roots of different tomato cultivars and wild related species. Plant Cell Tissue and Organ Culture, v. 65, p. 37-44, 2001.

ROSSeto, C. A. V.; VASCONCELOS, M. A. S.; CONEGLIAN, R. C. C.; SHIMUZU, M. K. Germinação de sementes de Passiflora alata préembebidas em soluções de ácido giberélico. Revista Brasileira de Fisiologia Vegetal, n. 11, p. 80-81, 1999. Suplemento. /Apresentado ao $7^{\circ}$ Congresso Brasileiro de Fisiologia Vegetal, junho de 1999-Resumo/

SEMANA INTERNACIONAL DA FRUTICULTURA E AGROINDÚSTRIA, 7º, Fortaleza-CE, setembro de 2000. Técnicas de cultivo do maracujá. Fortaleza: FRUTAL, 2000.29 p.

SAKAI, W.S. Simple method for differential staining of paraffin embedded plant material using toluidine blue O. Stain Technology, v.48, n. 5, p. 47$249,1973$.

SÃO JOSÉ, A.R. Maracujá: produção e mercado. Vitória da Conquista: UESB, 1994. 255p.

SKOOG, F.; MILLER, C.O. Chemical regulation of growth and organ formation in plant tissues cultured in vitro. Symposium of the Society of Experimental Biology, v. 11, p. 118-231, 1957.

TEIXEIRA, C.G. Maracujá. Campinas: Ital, 1994. 267 p. (Série Frutas Tropicais). 
THORPE, T. A. Morphogenesis and regeneration. In: VASIL, K. I.; THORPE,

T. A. (Ed). Plant cell and tissue culture. Kluwer Academic: Netherland,1994. p. 17-36.

VANDERPLANCK, J. Passion flowers. Cambridge Press: MIT, 1996. 224p.

VAN STADEN, J. ; SMITH, A. R. The sinthesis of citocinins in excised roots of maize and tomato under aseptic conditions. Annals of Botany, v. 42, p. $751-753,1978$.

VIEIRA, M. L. C.; APPEZZATO-DA-GLÓRIA, B.. Fundamentos e Aplicações da cultura de tecidos no melhoramento. In: NASS, L. L.; VALOIS, A. C. C.; MELO, I. S.; VALADARES-INGLIS, M. C. (Ed.) Recursos genéticos e melhoramento plantas. Rondonópolis: EMBRAPA,2001. p. 913-938 
APÊNDICES 
Apêndice 1- Passiflora cincinnata. Organogênese indireta a partir do disco foliar, aos 21 dias de cultura, em meio contendo $0,5 \mathrm{mg} \cdot \mathrm{L}^{-}$ ${ }^{1}$ de 6-BA e água de coco (5\%). A. A seta indica uma protrusão na superfície do calo (C) formado nas extremidades do explante. B. O mesofilo à direita apresenta intensa divisão no parênquima clorofiliano $(\mathrm{Pc})$ levando à formação do calo $(\mathrm{C})$; à esquerda o mesofilo pouco alterado. C. Meristemóide (M) formado a partir das camadas superficiais do calo (seta). ( $\mathrm{e}=$ estômato). Barras: $A=450 \mu \mathrm{m} ; \mathrm{B}=137,5 \mu \mathrm{m} ; \mathrm{C}=66,6 \mu \mathrm{m}$. 


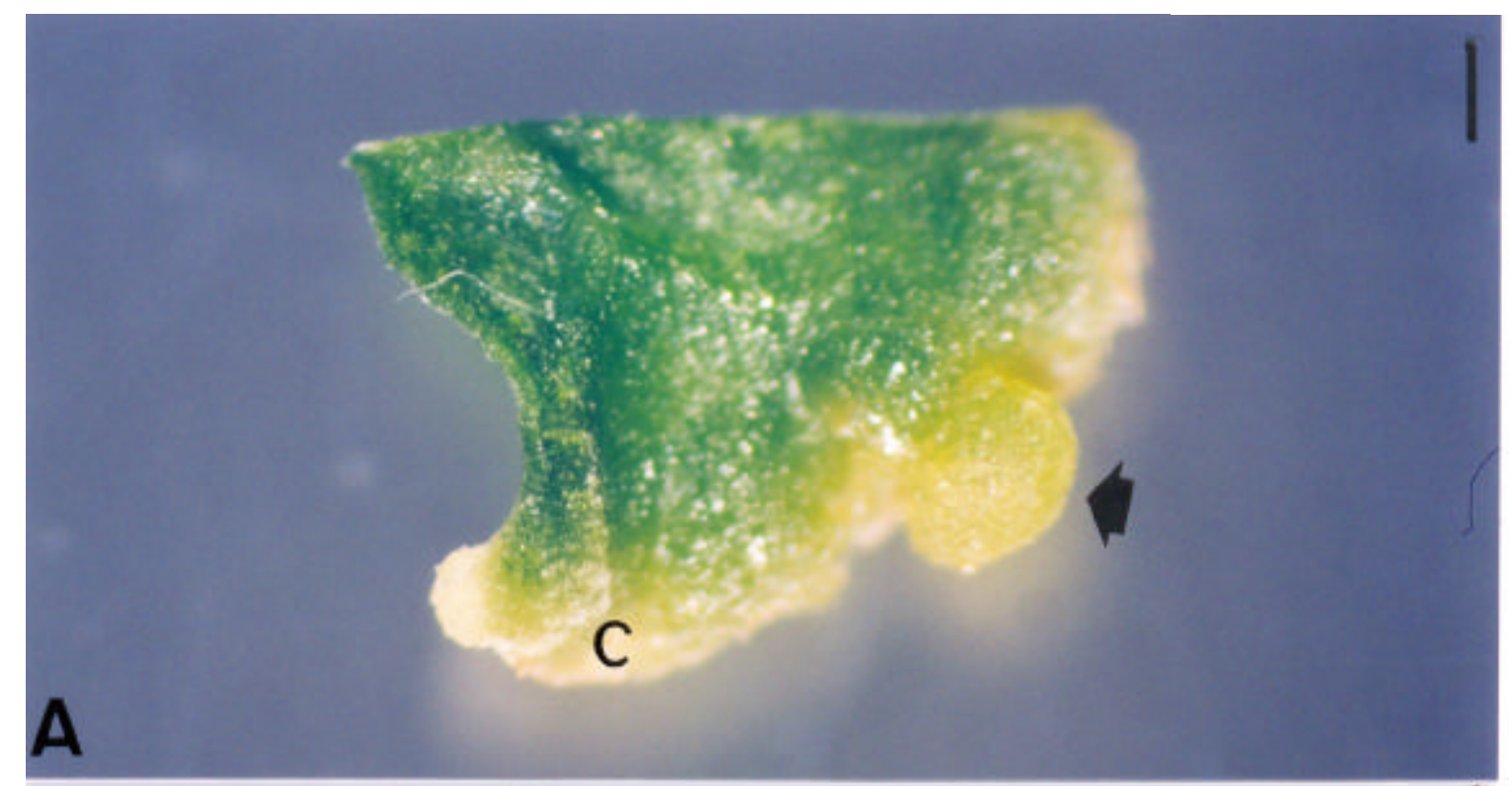

4

rin wor 10 11110

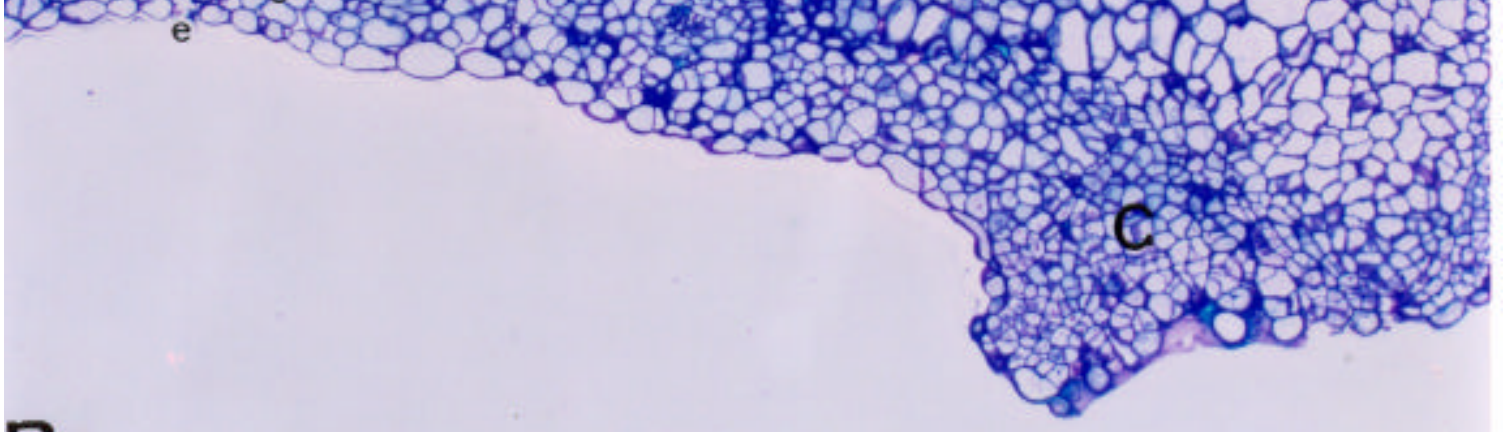

B

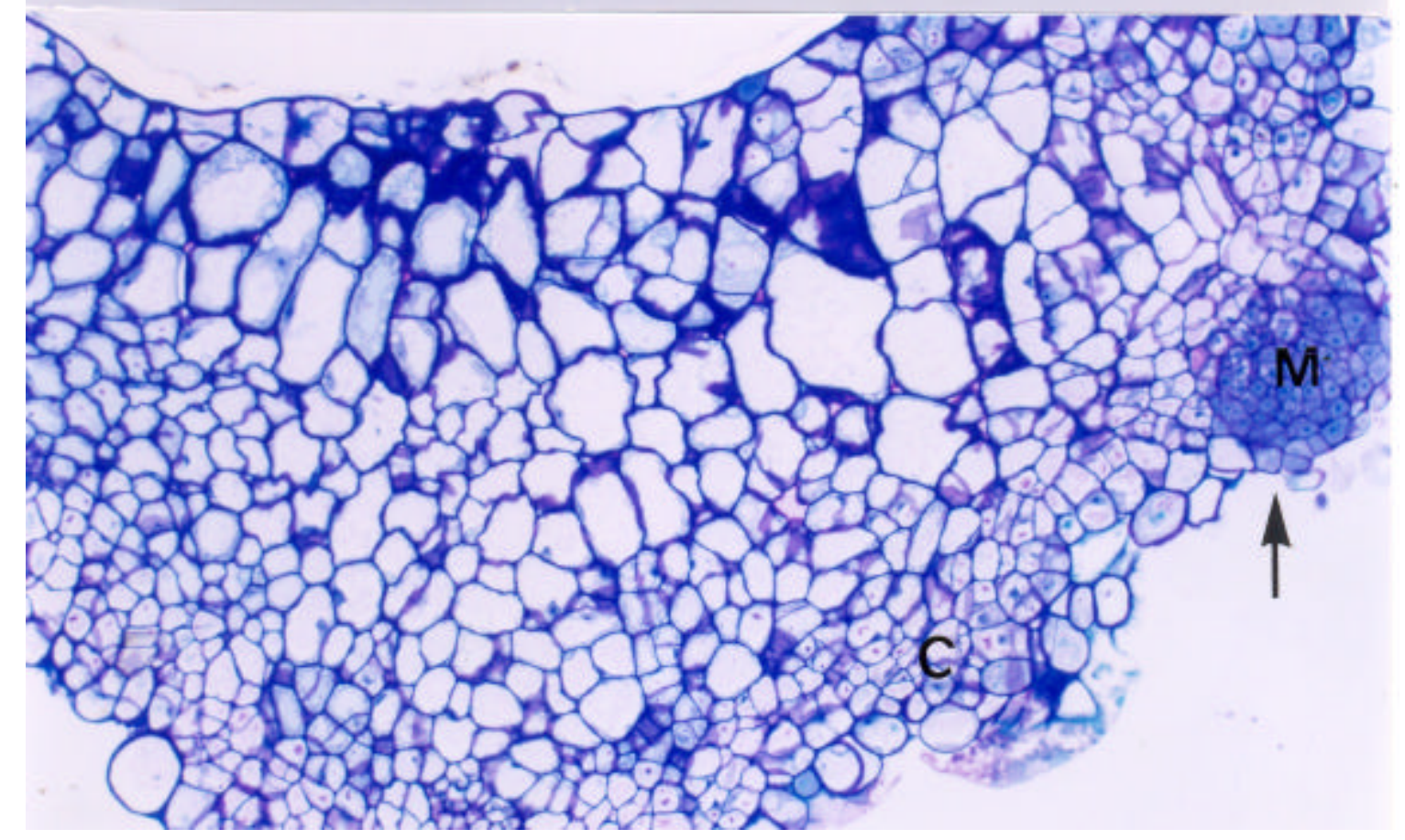


Apêndice 2 - Passiflora cincinnata. Organogênese indireta a partir do disco foliar, aos 21 dias de cultura, em meio contendo 1,0 mg.L' ${ }^{1}$ de 6-BA e água de coco (5\%). A. Formação de gemas (G) e meristemóides (setas) no calo. B. C. Detalhes do meristemóide (M). D. Seção transversal do disco foliar, mostrando origem da gema $(G)$ a partir do calo $(C)$. $(X=$ Xilema). Barras: $A=450$ $\mu \mathrm{m} ; \mathrm{B}=66,6 \mu \mathrm{m} ; \mathrm{C}=33,3 \mu \mathrm{m}, \mathrm{D}=66,6 \mu \mathrm{m}$. 


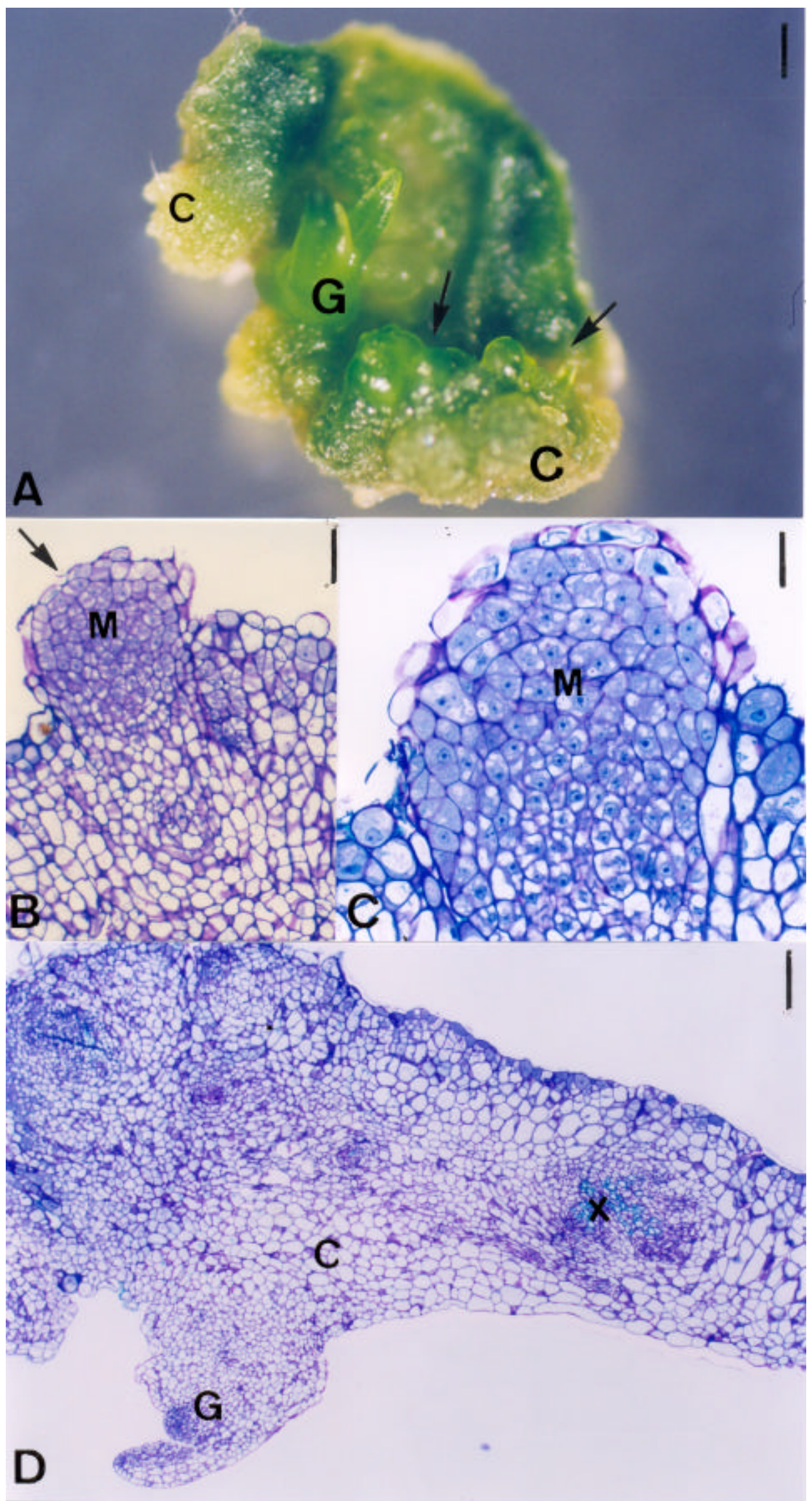


Apêndice 3 - Passiflora cincinnata. Organogênese indireta a partir do disco foliar, aos 28 dias de cultura, em meio contendo $0,5 \mathrm{mg} \cdot \mathrm{L}^{-1}$ de 6-BA e água de coco (5\%). A. Calo (C) formado nas camadas periféricas do explante, e formação da gema $(G)$ a partir deste. B. Detalhe da gema $(G)$ formada no calo (C). C. Seção transversal do disco foliar, mostrando a presença do nódulo vascular (N) na base da gema em formação, os quais estabelecem a conexão vascular entre a gema e o tecido do explante. Barras: $\mathrm{A}=870 \mu \mathrm{m} ; \mathrm{B}=450 \mu \mathrm{m} ; \mathrm{C}=199 \mu \mathrm{m}$. 


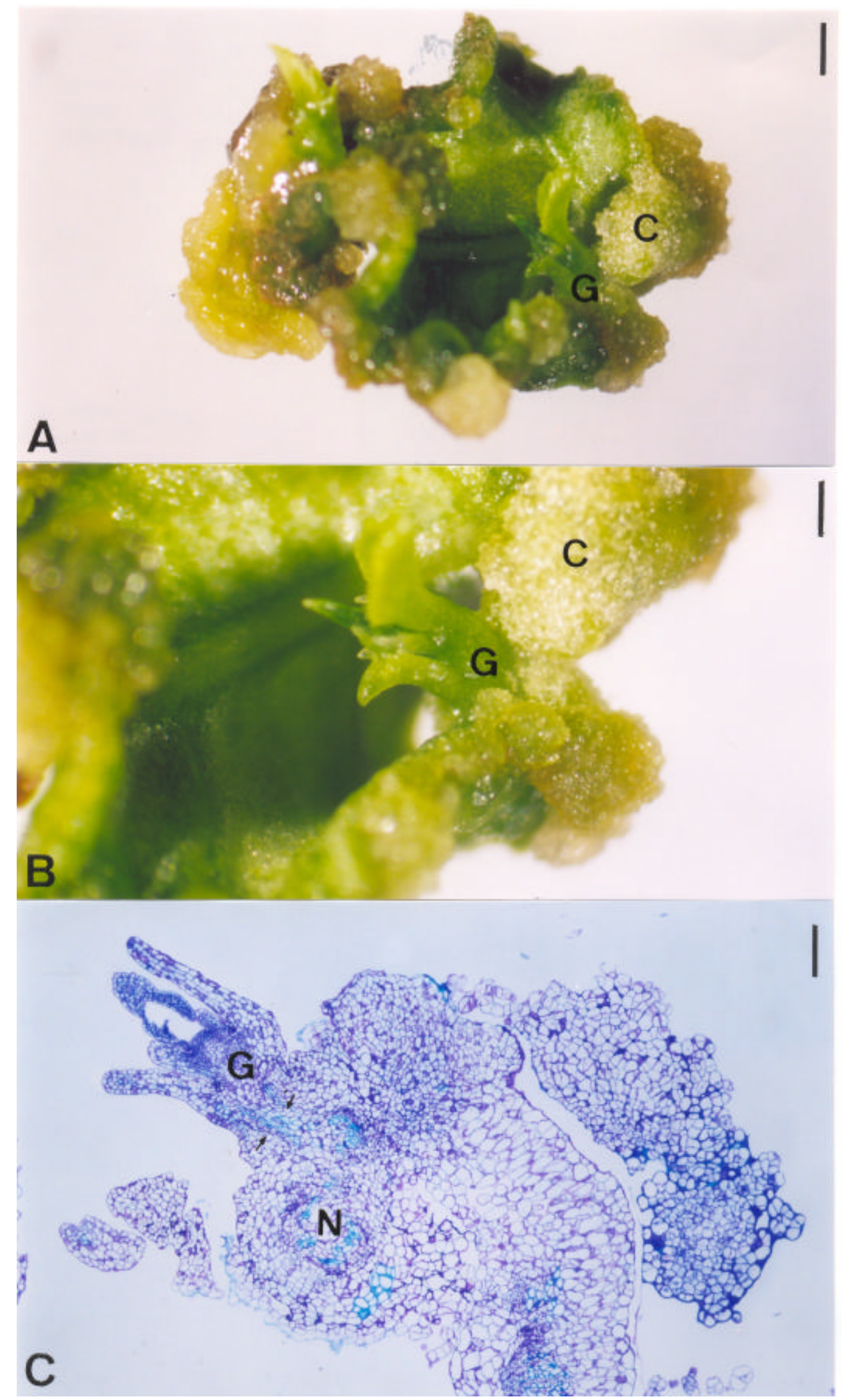


Apêndice 4 - Passiflora cincinnata. Organogênese direta in vitro em segmento de raiz, aos 28 dias em meio sem o regulador vegetal 6-BA e água de coco (5\%). A. A seta indica o início da formação de uma gema. B. A raiz apresenta início do crescimento secundário. A seta indica a conexão vascular entre a gema e o tecido do explante. C. Detalhe da figura anterior evidenciando a diferenciação vascular acrópeta (ponta de seta). ( $\mathrm{Cv}=$ câmbio vascular, $\mathrm{Ep}=$ epiderme, $\mathrm{E}=$ Endoderme, $\mathrm{F}=$ Floema, $\mathrm{G}=$ Gema, $\mathrm{Pc}=$ parênquima cortical, $\mathrm{Pe}=$ Periciclo, $X=$ Xilema). Barras: $A=450 \mu \mathrm{m} ; \mathrm{B}=66,6 \mu \mathrm{m} ; \mathrm{C}=$ $33,3 \mu \mathrm{m}$. 


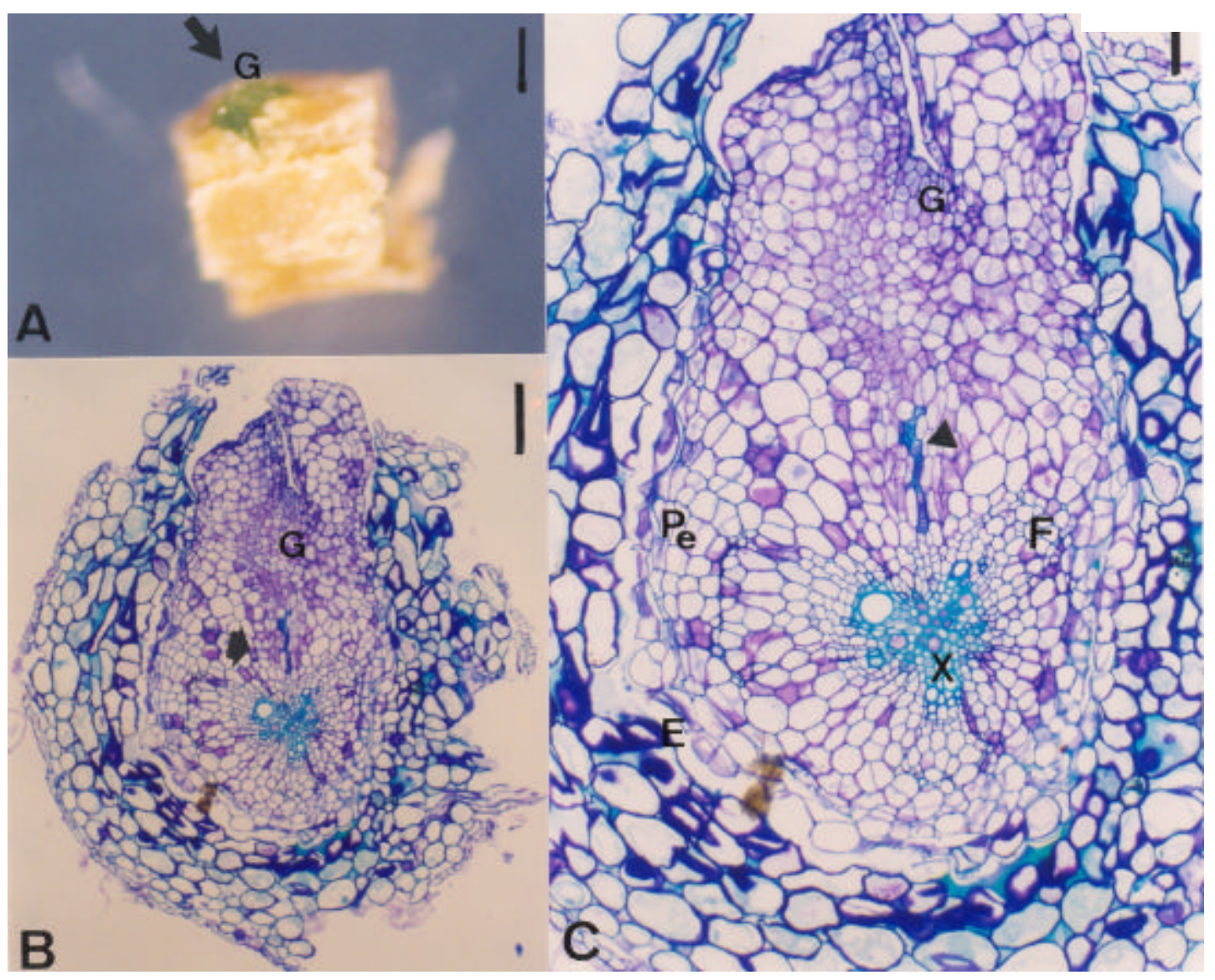


Apêndice 5 - Passiflora cincinnata. Organogênese direta in vitro em segmento de raiz a partir do câmbio vascular, aos 14 dias de cultura em meio contendo $0,5 \mathrm{mg} \cdot \mathrm{L}^{-1}$ 6-BA e água de coco $(5 \%)$. As setas indicam o meristemóide $(M)$. (CV=câmbio vascular, $\mathrm{E}=$ endoderme, $\mathrm{F}=$ floema, $\mathrm{X}=$ xilema). Barras: $\mathrm{A}=$ $137,5 \mu \mathrm{m}, \mathrm{B}=33,3 \mu \mathrm{m}, \mathrm{C}=17 \mu \mathrm{m}$. 


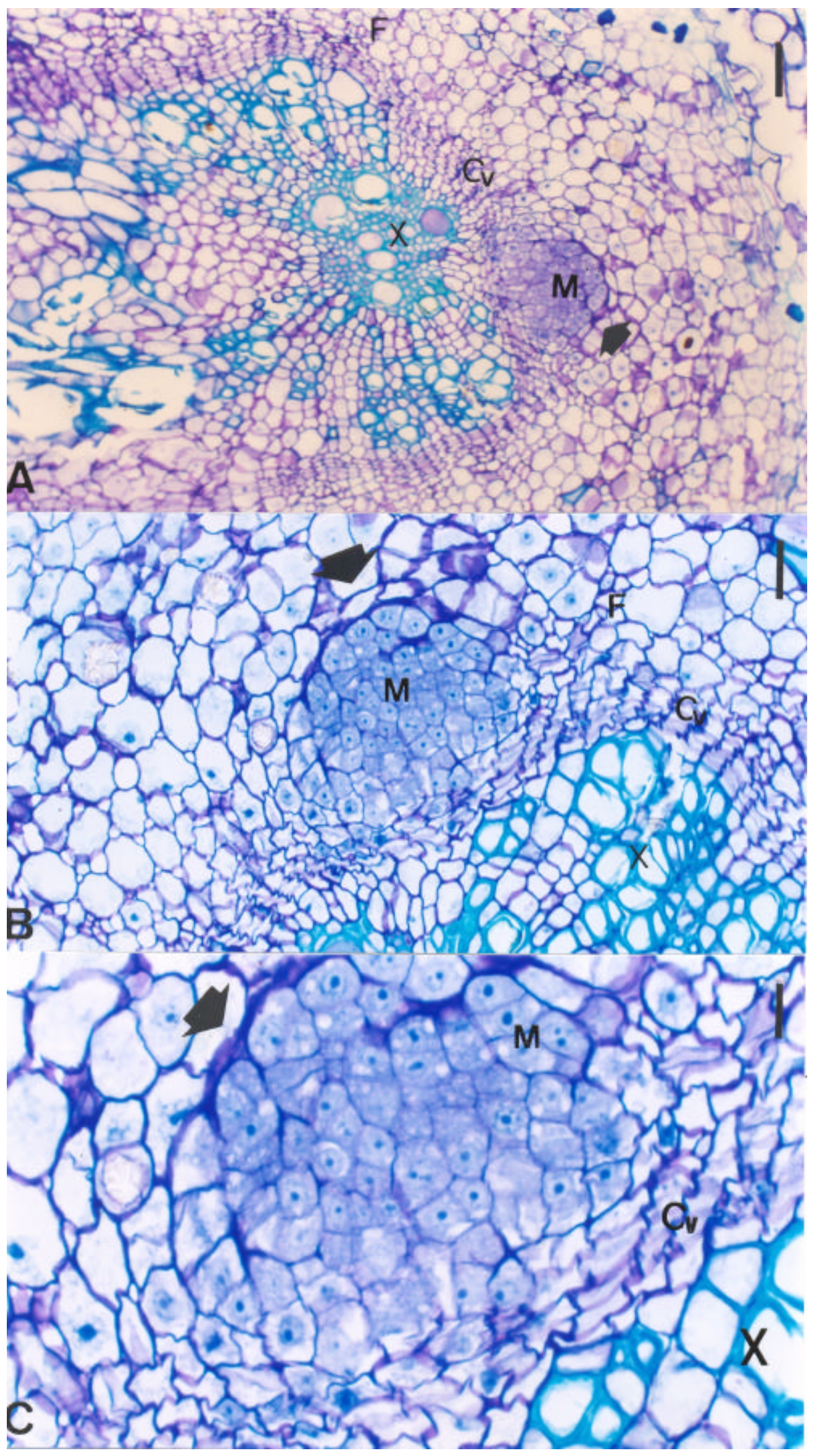


Apêndice 6 - Passiflora cincinnata. Organogênese indireta em segmento de raiz, aos 14 dias de cultivo in vitro em meio contendo $0,5 \mathrm{mg} \cdot \mathrm{L}^{-1}$ de 6-BA e água de coco (5\%). A. Detalhe do calo (C) formado na extremidade de uma raiz lateral. A seta menor indica um meristemóide e a seta maior uma gema. B. O calo (C) é formado a partir da proliferação do periciclo $(\mathrm{Pe})$ e na sua periferia surgem os meristemóides (setas). C. Detalhe dos meristemóides $(\mathrm{M})$ formados a partir das camadas periféricas do calo. $(E=E$ Endoderme, $F=$ floema, $X=$ Xilema). Barras: $A=$ $620 \mu \mathrm{m}, \mathrm{B}=328 \mu \mathrm{m}, \mathrm{C}=33,3 \mu \mathrm{m}$. 


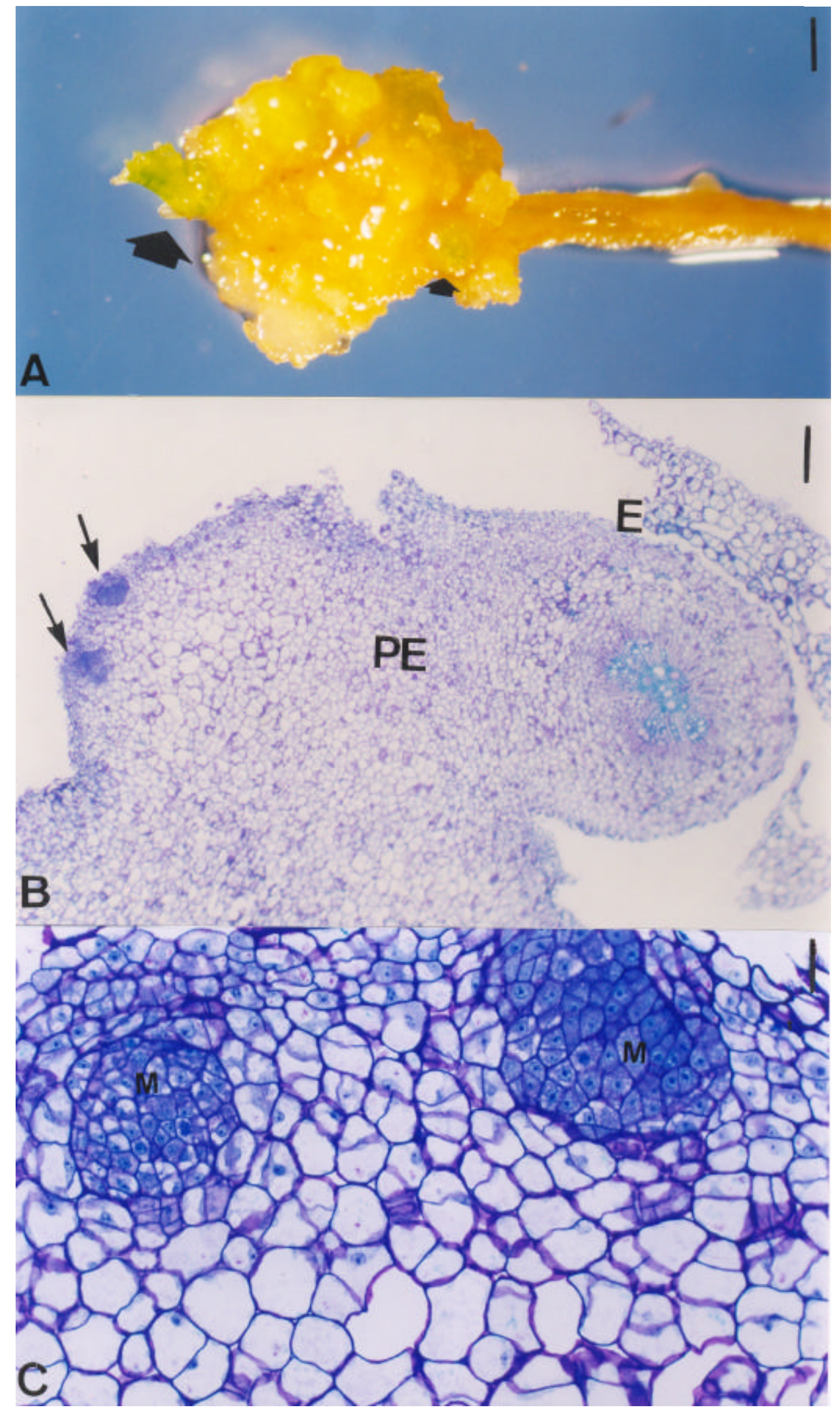


Apêndice 7 - Passiflora cincinnata. Organogênese direta na raiz primária do explante plântula aos 14 dias de cultivo in vitro, sem regulador vegetal 6-BA acrescido de água de coco (5\%). A. As setas indicam pontos verdes correspondentes aos meristemóides. BC. Observa-se a origem do meristemóide (setas) a partir do periciclo. $(\mathrm{F}=$ Floema, $\mathrm{PC}=$ Parênquima cortical, $\mathrm{Pe}=$ Periciclo, $\mathrm{X}=$ Xilema).

Barras: $A=380 \mu \mathrm{m} ; \mathrm{B}=66,6 \mu \mathrm{m} ; \mathrm{C}=33,3 \mu \mathrm{m}$. 


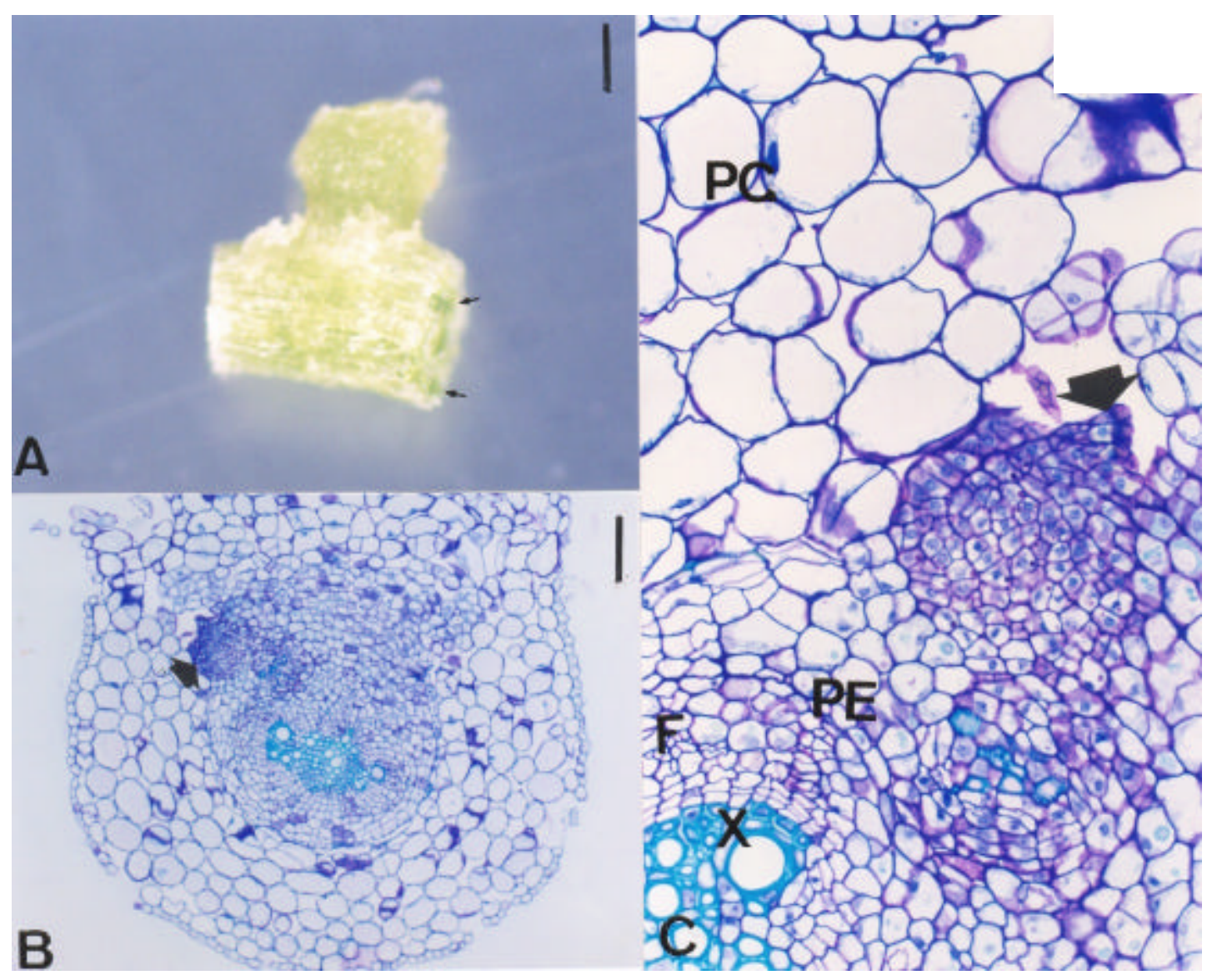

